Illinois State University

ISU ReD: Research and eData

Theses and Dissertations

$6-27-2020$

\title{
Sleuths As Social Activists: Negotiations Of Power \& Morality In Ya Sleuthing Stories
}

Heather Leigh Sanford

Illinois State University, hlsanf1@ilstu.edu

Follow this and additional works at: https://ir.library.illinoisstate.edu/etd

Part of the English Language and Literature Commons

\section{Recommended Citation}

Sanford, Heather Leigh, "Sleuths As Social Activists: Negotiations Of Power \& Morality In Ya Sleuthing Stories" (2020). Theses and Dissertations. 1305.

https://ir.library.illinoisstate.edu/etd/1305

This Thesis is brought to you for free and open access by ISU ReD: Research and eData. It has been accepted for inclusion in Theses and Dissertations by an authorized administrator of ISU ReD: Research and eData. For more information, please contact ISUReD@ilstu.edu. 


\section{SLEUTHS AS SOCIAL ACTIVISTS: NEGOTIATIONS OF POWER \& MORALITY IN YA}

\section{SLEUTHING STORIES}

\section{HEATHER LEIGH SANFORD}

\section{Pages}

In "Sleuths as Social Activists: Negotiations of Power \& Morality in YA Sleuthing Stories" I aim to explore how adolescent sleuthing stories intersect with negotiations of power, subjectivity, and relationality within the structures and confines of adolescent literature to challenge oppressive paradigms. This project will begin with a focus on gender dynamics, using ethics of care to compare Wendelin Van Draanen's girl sleuth Sammy Keyes to Anthony Horowitz's boy sleuth Alex Rider. This analysis of gender will then expand into an intersectional exploration of how age and race additionally implicate how Sammy Keyes and Alex Rider negotiate power and morality in their sleuthing pursuits, including an examination of how their whiteness disproportionately privileges these characters at the expense or erasure of marginalized groups. Finally, I will argue that relationships are presented differently in sleuthing stories featuring an individual agent, such as Sammy Keyes or Alex Rider, when compared to multi-agent sleuthing stories such as Bond Team in A.J. Butcher's Spy High series or in the tabletop role-playing game BubbleGumshoe: A Teen Detective Story Game created by Emily Care Boss, Kenneth Hite, and Lisa Steele. In making this comparison, I will highlight components of single-agent and multi-agent sleuthing stories that I argue are key to the sleuthing story's ability to act as a counternarrative to oppressive systems. 
KEYWORDS: Adolescent Literature, Detective Fiction, Ethics of Care, Power, Morality, Sleuth, Counternarrative 
SLEUTHS AS SOCIAL ACTIVISTS: NEGOTIATIONS OF POWER \& MORALITY IN YA SLEUTHING STORIES

HEATHER LEIGH SANFORD

A Thesis Submitted in Partial

Fulfillment of the Requirements

for the Degree of

MASTER OF SCIENCE

Department of English

ILLINOIS STATE UNIVERSITY

2020 
(C) 2020 Heather Leigh Sanford 
SLEUTHS AS SOCIAL ACTIVISTS: NEGOTIATIONS OF POWER \& MORALITY IN YA SLEUTHING STORIES

HEATHER LEIGH SANFORD

COMMITTEE MEMBERS:

Mary Jeanette Moran, Chair

Roberta Seelinger Trites 


\section{ACKNOWLEDGMENTS}

This thesis is a love letter to the sleuthing stories I grew up with. To the authors whose words kept me glued to the page, sneaking books under my desk at school, squinting to read by moonlight after bedtime. To the characters who taught me to pursue important questions, even those without easy or comfortable answers. To the summers I spent playing Nancy Drew on CDROM with my grandfather. Thank you.

I am indebted to three scholars in particular, without whom this thesis would not have been written. First, to Mary Jeanette Moran, who has been more of a friend and mentor to me than I have words to describe. Mary has fielded my tears, frustrations, and anxieties with care and compassion. She has celebrated my successes and continually reminded me to find joy in the work we do as academics. And, of course, Mary is the person who introduced me to ethics of care, the study of which has not only been key to this thesis but has also, I believe, made me a better human. The second person I would like to thank is Roberta Seelinger Trites, who will also be my academic crush, and whose work on power and repression in adolescent literature is a consistent source of inspiration. Last but not least, to Meghann Meeusen, who believed in me when I didn't believe in myself. As an undergraduate in one of Meghann's children's literature courses, I asked Meghann, "How do I do what you do?” ... and here we are.

All of my love and gratitude to the friends and family who have given me their care and support. To my mom, who has shown me by example how to be a badass woman in a patriarchal world. To my grandfather, whose career as a detective has clearly had a profound impact on my life. To Megan and Hannah, whose friendship have somehow survived the miles between us. To my cohort, who have been a source of encouragement, inspiration, and validation every day for the last two years. To my husband and partner in life Drew, who encourages me to reach for my 
dreams even when that means moving our family to the middle of a cornfield. And finally, to my son, who is wriggling in my belly as I write this: I hope you are as passionate about social justice as you are about kicking me in the bellybutton.

H. L. S. 


\section{CONTENTS}

Page

ACKNOWLEDGMENTS

$\begin{array}{ll}\text { INTRODUCTION } & 1\end{array}$

Defining the "Sleuthing Story": A Note on Genre and Terminology 2

Identifying the Adolescent Sleuth 2

Sleuths as Social Activists: Adolescent Sleuthing as a Moral Action 5

Sleuthing as a Moral Response: Feminist Theories of Power, Morality, and Subjectivity 8

$\begin{array}{ll}\text { Looking Forward } & 19\end{array}$

CHAPTER I: MOTIVATION \& MORALITY: BECOMING THE ADOLESCENT SLEUTH 21

$\begin{array}{ll}\text { Sammy Keyes } & 23\end{array}$

$\begin{array}{ll}\text { Alex Rider } & 31\end{array}$

$\begin{array}{ll}\text { Conclusion } & 39\end{array}$

CHAPTER II: “THE PRIVILEGE OF SLEUTHING”: SUBJECTIVE POWER IN SLEUTHING

$\begin{array}{ll}\text { STORIES } & 41\end{array}$

Sleuthing as a Counternarrative to Aetonormativity 42

"The Privilege of Sleuthing": Historical Trends of Gender and Race in Sleuthing Stories 53

$\begin{array}{ll}\text { Conclusion } & 60\end{array}$

CHAPTER III: MOTIVATION \& MECHANISM: ADOLESCENT SLEUTHS IN

$\begin{array}{ll}\text { RELATIONSHIP } & 62\end{array}$

$\begin{array}{ll}\text { The Single-Agent Sleuth } & 63\end{array}$

$\begin{array}{ll}\text { Separation as Caring } & 63\end{array}$

$\begin{array}{ll}\text { Sleuthing as Self-Sacrifice } & 67\end{array}$ 
$\begin{array}{ll}\text { Multi-Agent Sleuthing } & 71\end{array}$

$\begin{array}{ll}\text { Relationship as Mechanism } & 71\end{array}$

$\begin{array}{ll}\text { Relationship as Compensation } & 74\end{array}$

$\begin{array}{ll}\text { Conclusion } & 78\end{array}$

$\begin{array}{ll}\text { Coda: A Final Statement } & 79\end{array}$

WORKS CITED $\quad 82$ 


\section{INTRODUCTION}

In her article "'Use Your Head, Judy Girl': Relationships, Writing, and an Ethic of Care in the Judy Bolton Mystery Series" Mary Jeanette Moran uses ethics of care to analyze the role of relationality in Margaret Sutton's Judy Bolton mystery series, originally published from 19321967. In this series, Moran writes, "[R]elationships primarily serve as a source of strength but still evoke a threat to women's selfhood. Judy escapes this threat by enacting a feminist ethic of care that uses the writing process to simultaneously meet her own needs and the needs of others" (22). Moran's analysis highlights how an ethic of care uniquely manifests in the Judy Bolton series to "challenge restrictive notions of gender," particularly those that associate emotional labor with femininity and intellectual labor with masculinity (22). This is just one example of how adolescent sleuthing stories have historically engaged with systemic oppression.

Building on Moran's work on this particular series, I am interested in how a broader range of sleuthing stories intersect with negotiations of power, subjectivity, and relationality within the structures and confines of adolescent literature to challenge oppressive paradigms. This project will begin with a focus on gender dynamics, using ethics of care to compare Wendelin Van Draanen's girl sleuth Sammy Keyes to Anthony Horowitz's boy sleuth Alex Rider. This analysis of gender will then expand into an intersectional exploration of how age and race additionally implicate how Sammy Keyes and Alex Rider negotiate power and morality in their sleuthing pursuits, including an examination of how their whiteness disproportionately privileges these characters at the expense or erasure of marginalized groups. Finally, I will argue that relationships are presented differently in sleuthing stories featuring an individual agent, such as Sammy Keyes or Alex Rider, when compared to multi-agent sleuthing stories such as Bond Team in A.J. Butcher's Spy High series or in the tabletop role-playing game BubbleGumshoe: A 
Teen Detective Story Game created by Emily Care Boss, Kenneth Hite, and Lisa Steele. In making this comparison, I will highlight components of single-agent and multi-agent sleuthing stories that I argue are key to the sleuthing story's ability to act as a counternarrative to oppressive systems.

\section{Defining the "Sleuthing Story": A Note on Genre and Terminology}

The term "sleuthing stories" may seem to imply that it can be used to reference any mystery story, or specifically detective stories. However, I am using "sleuthing stories" to refer to a particular type of investigative story that can be found in both detective and spy fiction for young adults. As I will elaborate, defining this genre begins with identifying a power struggle between an adolescent character and an authority in a government institution, typically some form of law enforcement. This power struggle must critique the institution in some way that presents a mystery to be solved, evoking a moral response from the adolescent which prompts them to attempt resolution through "sleuthing."

\section{Identifying the Adolescent Sleuth}

Although I argue for a broader conceptualization that includes spy fiction, my definition of "sleuthing" has roots in the child detective genre. Chris McGee's dissertation, titled "The Mysterious Childhood: The Child Detective from the Hardy Boys to Harry Potter," views all detective fiction under the umbrella of mystery narratives. McGee quotes John G. Cawelti, who asserts that a narrative must meet three fundamental criteria in order to be considered a mystery:

(1) there must be a mystery, i.e., certain basic past facts about the situation and/or a number of the central characters must be concealed from the reader and the protagonist 
until the end; or, as in the case of the inverted procedural story the reader must understand that such facts have been concealed by the protagonist; (2) the story must be structured around an inquiry into these concealed facts with the inquirer as protagonist and his investigation as the central action; however the concealed facts must not be about the protagonist himself; (3) the concealed facts must be made known at the end. (Cawelti; qtd. in McGee 8)

Building from this definition by Cawelti, McGee draws a distinction between the child detective and the adult detective: “[Children's detective fiction books] are preoccupied with the power relationship with an adult world that hides secrets, and a childhood world full of burgeoning young sleuths unwilling to accept the delusional narratives that adults offer to explain the secrets they themselves often can't understand, such as sex and death" (9). Thus, to roughly paraphrase McGee's definition of a child detective story: (1) it must be centralized around a pursuit of concealed knowledge or information and the investigation thereof; (2) the concealed information cannot be directly about the protagonist, though the protagonist must be the one in pursuit of the concealed information; (3) the plot must culminate in a grand reveal of this information; and (4) the central themes of the narrative must feature a tension between an adult (or adults) who conceal knowledge and a child who seeks to uncover that knowledge.

This definition suits the child spy just as well as it does the child detective and applies to their adolescent counterparts as well. Spies are not always in pursuit of a mystery; I have limited experience in the world of adult spy fiction, but the genre in its typical form includes an information-dump which happens at the beginning of the narrative so that the spy can understand and follow a set of instructions which they are expected to have completed by the end of the narrative (they are given a mission, and that mission is expected to be completed). The classic 
plot of a spy novel is more action-oriented than that of the classic detective novel, which is more interested in the protagonist's use of logic and reason.

Child and adolescent spies, however, are different. As in the cases of both Alex Rider and Bond Team, which I will demonstrate in greater detail in the chapters to follow, the young spy often has important information concealed from them by an adult. An integral part of young spies' narrative arcs is to uncover this deception and seek that information for themselves, a process that typically creates, reveals, or intensifies a tension between the young spy/spies and the adult(s) who concealed the information. This deception thus creates a mystery to be solved, one centered on a tension between adults as the holders of knowledge and children/adolescents as the seekers, the grand reveal of which is tied to the climax of the novel. For these reasons, I contest that the young spy is only superficially different from the young detective. While McGee's definition of the child detective is specifically focused on individual tensions between child and adult characters, I am interested in the tensions between young characters and institutions, which, as I will demonstrate in the coming chapters, are key components of adolescent sleuthing stories.

This connection thus calls for a broader term of identification which includes both the adolescent detective and the adolescent spy. This is where the term "sleuth" comes in handy; it is often conflated with detective, but its meaning is subtly different. A detective is someone whose occupation includes solving mysteries. For adult detectives, detective-work is typically an official title and the means through which they earn an income. Child detectives are motivated through other means, however, and the term "child detective" often refers to a child who consistently solves mysteries even though they are not usually earning an income from the job. As in the examples of Alex Rider and Bond Team, young spies also often do not earn an income 
- an issue of exploitation which often underscores the tension between the young spy and the adults who "hire" them - and solve mysteries just as frequently as the young detective. The term "sleuth" is broader than "detective" in that it can refer to anyone who investigates, which describes both the young detective and the young spy. Therefore, the term "sleuthing stories" feels apt for describing a genre that includes both of these kinds of stories.

\section{Sleuths as Social Activists: Adolescent Sleuthing as a Moral Action}

While all sleuthing stories can be considered mysteries, not all mysteries involve "sleuthing" in the way that I am identifying. McGee offers a useful start in his identification of a power struggle between child(ren) and adult(s) around the concealment and subsequent attainment of knowledge. However, as I argue in the next section, sleuthing stories - particularly, adolescent sleuthing stories - are unique in additional ways which are worth investigating. McGee established that the key distinction between a child detective story and an adult detective story lies in a power struggle between an adult (or adults) who conceal knowledge and a child who seeks to uncover that knowledge. While I agree with this assessment and argue for its broader application beyond the child detective to adolescent sleuths, I do not think that the genre of the adolescent sleuthing story can be pinpointed to just this one distinction. I contend that what makes adolescent sleuthing stories unique is the tension between the adolescent sleuth and an authority in government institutions. In adolescent sleuthing stories, the protagonist is compelled to fill a gap in the government institution which the usual (adult) agents of authority cannot or will not fill themselves. This narrows the genre of adolescent sleuthing stories in three ways. First, the adolescent protagonist must be engaged in some kind of conflict with an authority in a government institution; while tension between an adolescent and institutions has 
long been established as a foundational criterion of young adult literature (as I will discuss in chapter two with regard to Roberta Seelinger Trites' work on power structures), this particular genre specifically portrays conflict with the institution of government authority, usually police or some other form of law enforcement. Importantly, such circumstances must necessarily include a critique of the legal or government system which hails the protagonist to take action. Second, this gap must pose some kind of mystery to be solved. This mystery, as McGee points out, is typically rooted in some kind of deception or concealment of knowledge on the part of an adult toward a child (or in this case, adolescent) who then seeks to uncover that deception or gain that knowledge for themselves. Third, the protagonist must choose (and be enabled) to respond to this set of circumstances through sleuthing.

To illustrate my point, consider a text such as Angie Thomas's The Hate U Give, which is a critique of law enforcement specifically focused on the issue of police brutality. This text features an adolescent protagonist who is responding to a noticeable gap in the government institutions of the police and the justice system (institutionalized violence against people of color), but the gap does not present a mystery to be solved (the cause of the problem is obviously racism), and so sleuthing is not a necessary response to the situation. Instead, Starr Carter responds to the gap through other methods of social action. The Hate U Give therefore cannot be classified as a sleuthing story. However, Sammy Keyes notices a gap in the government institution of the police when she tries to give her testimony after witnessing a robbery and is discounted for being a "little girl" (Van Draanen 22). This gap opens a mystery to be solved the mystery of who committed the robbery, since Sammy doubts that the police are giving a sincere effort toward the case, and so Sammy responds to the circumstances through sleuthing. 
For Sammy, sleuthing is a type of social action that she sees fit to take, and is enabled to take, in these circumstances. ${ }^{1}$

For the adolescent protagonist, sleuthing is an important form of social action given that adolescents are often considered (by adults) to be too young or to lack the appropriate qualifications to act themselves as agents of institutional authority; this stands in contrast to agents such as the (adult) detective or police officer who is sanctioned through their profession to act as such an authority. Because of this positioning, adolescent protagonists have to find their own way of filling the noticed gap in these stories. Sleuthing for the adolescent protagonist is not a job, but a moral response. The character's sense of ethical reasoning, individual subjectivity, and relational network greatly influence whether the protagonist chooses to take action, what action(s) they choose to take, and how those actions are employed. These considerations are critical as adolescent sleuths discover, as Trites observes about YA literature in general "their place in the power structure" and "learn[s] to negotiate the many institutions that shape them" (x).

Rooted in a perspective of feminist ethics and theories of power, my thesis seeks first to investigate how the imperative to become a sleuth is, for the adolescent protagonist, steeped in a dilemma of separation versus attachment. I will then consider how subjectivity influences these negotiations, focusing specifically on gender, age, and race. Finally, I will explore how negotiations of power, morality, and subjectivity are further complicated by relationality. The final process will demonstrate the complex web of dynamics that teen sleuths must negotiate as

\footnotetext{
${ }^{1}$ Certain factors may explain why teen sleuths tend to be white, like Sammy. I will explore this further in Chapter Two.
} 
they engage within, around, and against legal institutions and government authorities, navigating a liminal space between oppressor and oppressed in order to fill a gap in their community.

\section{Sleuthing as a Moral Response: Feminist Theories of Power, Morality, and Subjectivity}

I am proposing that sleuthing is a type of moral response to a particular kind of problematic power dynamic. This power dynamic is rooted in subjectivity and relationality, which are key components of feminist ethics of care. This is why I have seated this thesis in feminist ethics of care. In this section, I will provide some background on the history of feminist ethics of care, place it within the larger context of feminist theories of power, and connect these theories to a larger discourse of power negotiations in adolescent literature.

To place feminist ethics of care in context, we have to begin with Lawrence Kohlberg, whose interest in moral development came out of a post-Holocaust wave of social scientists interested in using their fields to understand human morality. Kohlberg was interested in establishing a theory of moral development which could be used by educators to develop a curriculum of moral education. Building from Jean Piaget's stages of cognitive development, Kohlberg's theory identifies three key "levels" of moral development, broken down further into a total of six individual "stages." The theory suggests that humans begin at the lowest stage of moral development and progress linearly throughout the stages until the highest level is achieved (Kohlberg and Hersch 54).

In the earliest stages of moral development, the preconventional level, Kohlberg claims that children are able to understand their behaviors as good or bad but primarily associate these ideas with fear of punishment or a desire for reward (54). After the preconventional level comes the conventional level, which is largely concerned with conforming to the social order and 
maintaining the status quo (55). For one to achieve the highest stages of moral development, housed in the postconventional, autonomous, or principled level, one must have accepted as true the "universal principles of justice, of the reciprocity and equality of human rights, and of the respect for the dignity of human beings as individual persons" (55). In other words, "[t]he principle central to the development of stages of moral development $[\ldots]$ is that of justice. Justice, the primary regard for the value and equality of all human beings and for reciprocity in human relations, is a basic and universal standard" (56, italics in original).

Working as Kohlberg's assistant in the 1970s, Carol Gilligan noticed a significant flaw in this research: that all his research participants were white, male, and middle-class. This was not an uncommon practice at the time and reflected an assumption of male behaviors as the norm. ${ }^{2}$ Gilligan refers to this fallacy within the human sciences as "theories of human development which turn out to be theories about men" (xxiii). ${ }^{3}$ The implication of this fallacy, Gilligan points out, is that "[t]he disparity between women's experience and the representation of human development, noted throughout the psychological literature, has generally been seen to signify a problem in women's development" (2). In other words, when women appeared to be consistently failing to achieve "higher" stages of moral development according to Kohlberg's theory, this was assumed to be evidence that women simply were not capable of achieving the same level of moral development - the same understanding and appreciation of "justice" - as men.

In response to this exclusionary and sexist logic, Gilligan's own research sought to develop a theory of moral development which included both male and female research

\footnotetext{
${ }^{2}$ In light of evolving understandings of gender and sex, today we might refer to these as "masculinized" behaviors rather than strictly "male." I am using language here that reflects the language used when these theories were originally established.

${ }^{3}$ More specifically, white middle-class men.
} 
participants. In her groundbreaking study In A Different Voice: Psychological Theory and Women's Development published in 1982, Gilligan found that the women in her research tended to operate from an inherent valuing of relationship (termed an ethic of care), while the men in her research tended to operate from an inherent valuing of law, order, and fairness (termed an ethic of justice). Gilligan is careful to qualify, however, that these two modes of ethical reasoning do not arise out of an inherent difference based on gender. She emphasizes adolescence as a key period for moral development, because:

during this time both sexes experience a conflict between integrity and care. But approached from different perspectives, this dilemma generates the recognition of opposite truths. These different perspectives are reflected from two different moral ideologies, since separation is justified by an ethic of rights while attachment is supported by an ethic of care $[\ldots .$.$] Thus the counterpoint of identity and intimacy that marks the$ time between childhood and adulthood is articulated through two different moralities whose complementarity is the discovery of maturity. (164-65)

In other words, whether a person is encouraged to operate from an ethic of care or an ethic of justice is not exclusively determined by whether the person holds the subjective position of male or female (not to mention, of course, gendered subjectivities outside of those two possibilities), but by how an individual negotiates the dilemma of separation versus attachment that, according to Gilligan, marks adolescence.

Defining adolescence in this way becomes complicated when I consider Trites' definition of adolescent literature. "Power," according to Trites, is even more fundamental to adolescent literature than growth. During adolescence, adolescents must learn their place in the power structure. They must learn to negotiate the 
many institutions that shape them: school, government, religion, identity politics, family, and so on. They must learn to balance their power with their parents' power and the power of the other authority figures in their lives. And they must learn what portion of power they wield because of and despite such biological imperatives as sex and death. Foucault tells us that it is in the very nature of power to be both enabling and oppressive because it is omnipresent $[\ldots .].[\mathrm{I}] \mathrm{n}$ adolescent literature, power is everywhere. (x) Taking Gilligan's definition of adolescence and Trites' definition of adolescent literature in dialogue with each other suggests (1) that negotiations of morality and power are inherently inseparable and (2) the processes of these negotiations are, together, integral to the genre of adolescent literature.

Feminist theories of morality and power demonstrate beautifully negotiations of morality and power are also fundamentally tied to subjectivity. According to Trites, "Identity politics matter most in adolescent literature [...] in terms of how an adolescent's self-identifications position her within her culture. How an adolescent defines herself in terms of race, gender, and class often determines her access to power in her specific situation" (47).

As I have said, adolescent sleuthing stories are unique in that the genre requires some gap to exist in the government authoritative structure that adults cannot or will not fill themselves, forcing the protagonists into a dilemma of "care" versus "justice," a dilemma that is rooted in the protagonist's subjective power. Sara Ruddick, in Maternal Thinking, published just a few years after Gilligan's In a Different Voice, draws a distinction between a masculinized philosophy of reason, rooted in detachment (or in Gilligan's terms, separation) and a feminized or "maternal" philosophy that she argues is rooted in love (or in Gilligan's terms, attachment). While Ruddick, 
like Gilligan, is primarily interested in gender, she also draws a greater connection between reason and access to power ${ }^{4}$ :

To cast one's lot with reason meant staying with the men, on the right side of power. Philosophers have often suggested that people of superior rationality are justified in excluding and dominating others. Aristotle puts the matter plainly: free men and women are superior to slaves because the former are reasonable while the latter have only enough rationality to hear and obey orders. Similarly, free women are rightfully subordinate to free men. Although the free woman, unlike the slave woman or man, has some deliberative capacity, in her this capacity is weakly developed; she cannot govern herself but must submit to the deliberative capacity of men. (6)

This synopsis describes a chilling history of how "reason" and "rationality" have been used by those in power to justify separation and oppression in Western culture, a dynamic that Ruddick traces all the way back to Aristotle and that is so embedded in our society that it is still the status quo over two thousand years later.

Of course, contemporary Western society functions differently from the society in which Aristotle lived. Freedom, in Aristotle's meaning, was mostly a class distinction and lacked the association with race that was later established because of the transatlantic slave trade. However, as we can see in Ruddick's account, Aristotle's society was no stranger to misogyny. Aristotle associated reason and rationality with men and argued that women are simply incapable of such complex processes. Therefore, women were expected to be subservient to men regardless of whether they were free or enslaved. This expectation of servitude has only become more

\footnotetext{
${ }^{4}$ Specifically, the struggles of white women. Much of feminist ethics of care, especially these early developments, are problematically and unreflectively rooted in white feminism.
} 
complex over time; as Western society has globalized, the expectation of servitude has adjusted accordingly. Those in power continue to shape the narrative of who is deserving of power and who is not. Additionally, these divisions of power and oppression continue to be rooted in "reason" and "rationality" as these concepts are defined by those in the greatest position of power. For example, as Patricia Hill Collins notes in Black Feminist Thought:

When white men control the knowledge validation process, [this process] can work to suppress Black feminist thought. Given that the general culture shaping the taken-forgranted knowledge of the community of experts is permeated by widespread notions of Black and female inferiority, new knowledge claims that seem to violate these fundamental assumptions are likely to be viewed as anomalies (Kuhn 1962). Moreover, specialized thought challenging notions of Black and female inferiority is unlikely to be generated from within a white-male-controlled academic community [....] While Black women can produce knowledge claims that contest those advanced by the white male community, this community does not grant that Black women scholars have competing knowledge claims based in another knowledge validation process. As a consequence, any credentials controlled by white male academicians can be denied to Black women producing Black feminist thought on the ground that it is not credible research. (203-04) As women in a broad sense were deemed inferior to men in Aristotle's time because of patriarchal power hierarchies, Collins' account demonstrates how the rise of white supremacy and other forms of oppression have leaned on these ancient notions of "reason" and "rationality" to establish and maintain white supremacist heteropatriarchal ableist domination.

"Reason" and "rationality" have historically been used to determine who is subservient to whom, and as Magnet, et al., in "Feminism, Pedagogy, and the Politics of Kindness" delineate, 
expectations of servitude have become increasingly entangled with kindness and care. First, Magnet, et al., provide a helpful overview of when and how kindness and care became gendered/feminized in Western culture, rooting this cultural shift in the Industrial Revolution. During this time:

kindness came to be associated with the domestic realm and was contrasted with the masculine pursuit of industrial toil. As a result, kindness as an emotion was simultaneously feminized and devalued [and] became linked, disastrously, to selfsacrifice. $[\ldots .].[\mathrm{H}]$ istorically the turn away from kindness accompanied the rise of freemarket ideology in the nineteenth century, during which we saw the abolition of laws aimed at protecting people living in poverty and instead witnessed a heightened call for the importance of protecting one's own self-interest. (2-3)

Since this cultural shift, Magnet, et al., remark:

who is allowed to demonstrate kindness, and on behalf of whom, remains tied to existing structures of white supremacist heteropatriarchal ableist domination. That is, kindness has been and continues to be used to explicitly marginalize othered bodies. From the institutional exploitation of kindness to persuade women to work for lower wages, forego promotions, and sacrifice their own interests in the name of nurture and love $[\ldots]$ to the scripting of women of color as always-already angry and refusing to behave "kindly" or with gratitude to the institutions that oppress them. (2)

This cultural emphasis on individualism at the cost of the community harkens back to Gilligan's evocation of the attachment versus separation dilemma. How an individual internalizes and negotiates attachment and separation are greatly rooted in social conditioning, and the expectations of an oppressive society necessarily interpolate the oppressed in the conditions of 
their own oppression. The structures of a white supremacist heteropatriarchal ableist society, particularly one as deeply rooted in capitalism as Western culture, depends on this weaponization of care in order to shift that labor onto marginalized people. The weaponization of care is necessary in the exploitation of marginalized people, and that exploitation is necessary in order to sustain the structures of oppression that keep this system in place, to the benefit of only a select, privileged few.

Ironically, even as care is weaponized within this system, care is absolutely fundamental to keep the system alive. Virginia Held, for example, states in The Ethics of Care, "Care is probably the most deeply fundamental value. There can be care without justice [....] There can be no justice without care, however, for without care no child would survive and there would be no persons to respect" (17). Care is a fundamental necessity to the survival of the human race. The problem, therefore, is not in care itself or the practice of it, but in how white supremacist heteropatriarchal ableist domination has weaponized care as a tool of oppression.

This is why many feminist care ethicists advocate so strongly for a (re)conceptualization of care. As Moran proposes in “'Use Your Head Judy Girl’: Relationships, Writing, and an Ethic of Care in the Judy Bolton Mysteries," "The more we can conceive of an ethic of care as the product of choice, the farther we move away from a system that expects women - and women only - to have the capacity to care for others and to enact care no matter what the cost to themselves" (24). Deconstructing gendered notions of care is key to deconstructing gender oppression; in the meantime, caring remains a gendered form of labor.

Additionally, as Magnet, et al., explain, expectations of smiling servitude in today's society are tied not just into gender dynamics, but to the oppression of all marginalized bodies. This is particularly interesting in considering race and the adolescent sleuth. For example, 
BubbleGumshoe asserts that race and racial tensions can complicate sleuthing so much that players are advised to "decide if that's a game [you] want to play before you define your Sleuth by her race" (meaning that players should consider whether the world of the game will or will not include racism) (35). As I will elaborate further in chapter two, this cautionary advice regarding race demonstrates that racialized embodiment plays a critical role in how an adolescent character negotiates sleuthing, or if they are enabled to become a sleuth at all.

The concept of aetonormativity further expands this conversation of subjectivity in negotiations of power and morality, especially in the context of literature for children and young adults. Working from queer theory and the idea of heteronormativity, Nikolajeva develops the term aetonormativity to describe the phenomenon of "adult normativity that governs the way children's literature has been patterned from its emergence until the present day" (8). As she describes in Power, Voice and Subjectivity in Literature for Young Readers, the great irony of children's literature is that it seeks to "both $[\ldots]$ empower the child and $[\ldots]$ protect him from the dangers of childhood," which is the root tension of aetonormativity (20). Additionally, Nikolajeva explains that "[i]n terms of social conditions, in real as well as in fictive world, adults are and will always be superior to children. Here, power hierarchy is non-negotiable, unlike other heterological situations (gender, class, sexual preference), and power is inevitably selfreproducing" (203).

Adding to the considerations of gender and race described above, aetonormativity is key to the analysis of adolescent sleuthing stories. According to Trites:

Adolescents have power that becomes institutional power as they (necessarily) engage in the social forces that simultaneously empower and repress them [....] All YA novels depict some postmodern tension between individuals and institutions. And the tension is 
often depicted as residing within discursive constructs. Once protagonists of the YA novel have learned to discursively negotiate their place in the domination-repression chain of power, they are usually depicted as having grown. (52)

As I have mentioned, not only do adolescent sleuthing stories emphasize the "tension between individuals and institutions" in the interaction between the adolescent sleuth(s) and some form of authority in a government institution; these tensions are underscored by the tensions between adolescents and adults. While this statement in itself, as Trites argues, could be applied to a majority of adolescent texts, adolescent sleuthing stories are unique in that they are always engaged with some aspect of government authority, always contain some critique of that institution, and always depict an adolescent character who, as Trites ascribes to all young adult novels, has "power that becomes institutional power as they (necessarily) engage in the social forces that simultaneously empower and repress them."

I am interested in exploring what adolescent sleuthing stories have to offer in the difficult question of whether aetonormativity can be abolished, and how such a revolution might manifest itself. To reiterate, Nikolajeva states that within aetonormative structures, "power hierarchy is non-negotiable [...] and power is inevitably self-reproducing" (203). Understanding children and adolescents as an oppressed class, this excerpt from Paolo Friere's Pedagogy of the Oppressed offers additional insight:

The oppressed, having internalized the image of the oppressor and adopted his guidelines, are fearful of freedom. Freedom would require them to eject this image and replace it with autonomy and responsibility. Freedom is acquired by conquest, not by gift. It must be pursued constantly and responsibly. Freedom is not an ideal located outside of man; 
nor is it an idea of which becomes myth. It is rather the indispensable condition for the quest for human completion. (47)

Presenting adults as an oppressive class troubles, then, the adolescent pursuit of simultaneously rebelling against and seeking to achieve adulthood. Adolescent sleuthing stories, however, present an opportunity to interrogate these negotiations of subjectivity, power, and morality further. In the teen sleuth's imperative to work both within and around government authorities as aetonormative institutions, these stories hold the possibility for readers to imagine a solution to aetonormative oppression which questions the inevitability of becoming the oppressor.

Thus far, all of the theories I have presented are focused on the individual: the negotiations an individual must make when faced with a moral dilemma, the subjective power that an individual person holds, and all of the complexities therein. Bringing relationality into the equation, I return to Moran's analysis of Judy Bolton, in which she uses an ethics of care lens to examine Judy's ability to find strength in relationality while challenging patriarchal expectations of female martyrdom. This, Moran suggests, is unique in that Judy's “willingness to depend on others does not weaken her but rather presents a positive image of a different kind of strength, one that comes from interdependence rather than dependence" (23). This is significant because, "Feminist ethicists have discussed at length this alternative model of strength, many suggesting that guidelines for behavior should be centered around the premise of relationality: People are not isolated entities, but members of interconnected communities that shape and influence them as individuals and to which they owe responsibility" (23). Essentially, Moran claims that Judy Bolton embraces relationality as a key component of her sleuthing strategy and demonstrates how this type of strength is exemplary of contemporary discussions of feminist ethics and relational morality. Moran's analysis of how a single adolescent sleuth works in relationship with 
other people offers a foothold for analyzing how adolescent sleuths negotiate moral reasoning and subjective power within a group of sleuths, as in the case of Bond Team or in the scenario of the BubbleGumshoe RPG game.

\section{Looking Forward}

In the first chapter of this thesis, I will compare Sammy Keyes and Alex Rider and use ethics of care to demonstrate how each of these characters' motivations to become sleuths are rooted in a dilemma of separation versus attachment. I will argue that, in both cases, there is a deficit in the system of legal authority that Sammy and Alex are each uniquely empowered to solve and that it is through their respective moral lenses that they negotiate that power in order to take action.

I will expand this argument in the second chapter, in which I incorporate subjectivity in my analysis of power and morality in these texts. I will use my previous discussion of feminist ethics to begin the conversation with an expanded analysis of Sammy Keyes' gendered subjectivity. Then I will use Maria Nikolajeva's theory of aetonormativity to give an expanded analysis of Alex Rider's age-dependent subjectivity. Finally, the curious instructions presented in BubbleGumshoe will allow me to explore sleuthing as an exercise of white privilege (and, in a larger sense, an exercise of privilege in general). Anchoring my focus on gender, age, and race, I will demonstrate how these texts both mirror and challenge the adult-white-male dominated genre of detective fiction.

After these discussions of how morality and subjective power are integral to the sleuthing process, the third chapter will address relationality. In this chapter, I compare how the sleuthing strategies of single-agent sleuths (Sammy Keyes and Alex Rider) compare to those of multi- 
agent sleuths (Bond Team). I also analyze the complex system of relational network-building that is presented in BubbleGumshoe as a critical element of character creation and gameplay. My analysis of these texts, characters, and relational networks will build from the claims on negotiations of power, morality, and subjectivity I make in the first and second chapters and underscore the unique capability of adolescent sleuthing stories to dismantle the problematic binary between reason and relationship that has for too long justified the structures of oppression on which our society is built. 


\section{CHAPTER I: MOTIVATION \& MORALITY: BECOMING THE ADOLESCENT SLEUTH}

"And here I thought you were an anarchist, [Sammy Keyes]"

- Gina, Hotel Thief (Van Draanen 87)

In this chapter I will compare how Sammy Keyes and Alex Rider each become sleuths, analyzing their motivations through an ethics of care framework. My analysis will show that both Sammy and Alex come to this decision through a moral dilemma that is caused by a gap in authorities in government institutions. In critiquing these institutions, Sammy and Alex are each propelled into a crisis of separation versus attachment. Sammy and Alex each become sleuths as a moral action in response to this predicament.

Carol Gilligan's In a Different Voice presents her findings about moral reasoning in a binary. She observes that the men in her research tend to root their moral decisions in separation, individualism, rules, logic, and principled reasoning - qualities that, as Sarah Ruddick tells us, have historically been associated in Western culture with masculinity and patriarchal "rationality." This, as I described in the previous chapter, is the pattern that Lawrence Kohlberg's research identifies as the ideal standard for morality. The women in Gilligan's research, on the other hand, tend to root their moral decisions in attachment, connection, relationship, and contextual reasoning. Gilligan terms the first mode of moral reasoning an "ethic of justice" and the latter an "ethic of care." She sets up this binary in order to challenge the assumptions made about moral development by Kohlberg, assumptions that perpetuate long-held Western patriarchal assertions that women are incapable of being as morally virtuous as men. By identifying these correlations and defining these different modes of moral reasoning within their 
own identifiable parameters, Gilligan suggests that the reason women do not climb Kohlberg's stages of moral development is not because women are deficient in comparison to men, but because Kohlberg's stages are built under the problematic assumption that the experiences of one very particular group of people can serve as an accurate standard of measurement for all groups of people. Both an ethic of care and an ethic of justice, Gilligan argues, have the potential to be useful in moral decision-making and can be used by any person regardless of gender. Gilligan is interested in (1) highlighting how patriarchal expectations tend to enculture men to adopt an ethic of justice and women to adopt an ethic of care, and (2) challenging patriarchal assumptions that masculinized ethical reasoning is inherently superior to feminized ethical reasoning.

Feminist ethics of care as a field of philosophical discourse has since used Gilligan's initial research to consider how justice and care are negotiated in moral decision making and the implications thereof. The claim of this field is not to say that care ethics are better than justice ethics (although some individual scholars have certainly made arguments to this effect), or that only women can operate from an ethic of care and only men can operate from an ethic of justice. What the philosophy of feminist ethics of care does promote is that (1) all ethical reasoning is rooted in how an individual negotiates care and justice, (2) those negotiations are rooted in a fundamental dilemma between separation and attachment, (3) how an individual is conditioned to perform these negotiations is heavily encultured based on their subjective position within a society, and (4) the ways in which justice and care have historically been delineated among different groups of people in order to uphold white supremacist heteropatriarchal domination is problematic and worth critical analysis. For example, Virginia Held warns in her 2006 publication The Ethics of Care, "An ethic of care that extols caring but that fails to be concerned with how the burdens of caring are distributed contributes to the exploitation of women, and of 
the minority groups whose members perform much of the paid but ill-paid work of caring in affluent households, in day care centers, hospitals, nursing homes, and the like" (16). So, while Gilligan's initial work has certainly been taken up by some care ethicists in order to further describe what an ethic of care entails and develop a more prescriptive philosophy (see: Ruddick, Held, and Nel Noddings) the root of this theoretical framework is in description and explanation, which is my focus here as well.

Feminist ethics of care is a useful tool for understanding adolescent sleuthing stories because, I argue, care ethics focuses on the same types of negotiations as those which are central to the genre. In the following analysis of Sammy Keyes and Alex Rider, I focus on how they are each initially motivated to become sleuths and how these motivations are rooted in the dilemma of separation and attachment that a feminist ethics of care gives us language to understand. Additionally, I argue that this crisis is rooted in a conflict with authorities in government institutions that necessarily critiques these institutions and motivates Sammy and Alex to become sleuths in order to achieve what the adult authorities, as representatives of government institutions, cannot or will not do themselves.

\section{Sammy Keyes}

Between Sammy’s relationship with her grandmother and the barriers she must put up between herself and others, the ways in which Sammy must mediate her living situation emphasize Sammy's negotiation of the attachment-separation dialectic. In the first scene of Hotel Thief, Sammy is in Grams' apartment, prevented from going outside because of a neighbor who is bent on catching Sammy in the act of illegally living in the government-subsidized Senior Highrise: "[I]t's on account of Mrs. Graybill that I was stuck inside when I wanted to be 
outside," Sammy narrates. "And since there's not much for me to do because everything I own has to be able to fit inside Grams' bottom dresser drawer, I was using the binoculars to at least see what was going on outside" (Van Draanen 3). Sammy cannot leave the apartment because Mrs. Graybill poses a danger to Sammy and her grandmother. Sammy has to separate herself from other people and the outside world in order to protect herself and Grams. However, Sammy resists separation as much as the circumstances will allow. As Sammy uses binoculars to peer around the neighborhood from Grams' apartment window, she develops a deep familiarity with the people and places around her. She is not attempting to be covert at this moment; she even waves at some of the folks she spots, revealing a desire to connect despite knowing that nobody is going to see her when she is five stories above the ground (4).

In an ironic twist, Sammy's desire to connect with other people quickly leads her into questionable circumstances as she establishes an unwanted relationship with the story's villain. Peering curiously into the windows at the Heavenly Hotel, which is located just across from the Senior Highrise, Sammy is surprised to notice a robbery taking place in one of the rooms. She is even more surprised when the thief notices her in return:

For a second there I don't think he believed his eyes. He kind of leaned into the window and stared [at me], and I stared right back through the binoculars. Then I did something really, really stupid. I waved.

He didn't wave back. (6)

This wave is characteristic of Sammy's connective personality, as we can see from the previous descriptions in this scene of Sammy waving at other people. However, Sammy instantly regrets waving in this case, as it has let the thief know that she has seen him. 
While witnessing the crime without being seen would still place her in the moral dilemma of whether or not to report the crime, the fact that the thief has seen her has a critical impact on how Sammy responds to the situation. First, Sammy considers telling Grams, but decides against it; if she were to tell Grams about the robbery, then, "I'd have to tell her about how he saw me, and that would make her worry. I was worried, and if I was worried then you can just picture how Grams would be" (6, italics in original). So, Sammy decides not to tell Grams, out of a desire to both preserve her grandmother's image of her and out of a sense of responsibility for minimizing the amount of worry in her grandmother's life. This reasoning suggests that if the thief had not seen her, Sammy would have been more likely to tell Grams what she had seen. Sammy considers dialing 911 to give her witness statement directly to the police, "but the only phone in the apartment is in the kitchen and since Grams was in there making dinner I couldn't exactly go dialing Emergency without her knowing about it" (6). Sammy also considers walking to the police station but is still unable to leave the apartment due to the danger of being caught by Mrs. Graybill. Sammy is unable to contact the police without somehow involving Grams, which is an undesirable outcome because of Sammy's sense of care and responsibility toward Grams. Therefore, when Sammy ultimately decides to keep the incident a secret, it is an expression of her valuing of attachment. Sammy is concerned about Grams learning that she was seen by the thief, and this has a fundamental influence on Sammy's reasoning regarding whether she should give her testimony, and to whom. The text is clear that if Sammy had not been seen by the thief, therefore leaving Grams' emotional well-being unendangered, she would have felt more secure in confiding in Grams and/or the police. The boundaries Sammy establishes around these circumstances demonstrate a degree of separation in the service of attachment. 
Sammy's reasoning regarding whether or not to contact the police is also significant in that it presents a tension between Sammy and the police. While Sammy isn't necessarily antipolice, she is also anxious about drawing their attention to herself and Grams. As she relays in a later scene:

I don't mind policemen. Actually, when I was in the fourth grade I wanted to be one, but that was before Lady Lana left me with Grams and I had to start worrying about someone finding out. When you're living where you're not supposed to be living, it doesn't take long to figure out that you should stay away from people who ask nosy questions, and believe me, policemen like to ask lots of nosy questions. (18, italics in original) This tension highlights a gap in the legal authorities in Sammy's community (specifically, the police). While Sammy still sees the police as generally a source of protection and security - or at the very least, of holding the appropriate amount and type of authority to properly respond to a report of a robbery - she is also aware that this assessment of the police has limited application toward her and Grams. This is another example of Sammy employing the contextual, attachment-motivated mode of reasoning that marks an ethic of care. Even though Sammy holds a general principle that police are typically good, her living situation has forced her to confront this principle and question its universality.

Sammy's applications of care ethics are additionally complicated by her desire to care for others in balance with the need to protect herself and Grams. When Sammy is walking home from the mall the evening of the theft, she sees the police at the Heavenly Hotel collecting the testimony from the woman whose apartment was broken into, and Sammy feels compelled to offer her testimony. "I look at her for a minute, thinking that four thousand dollars is an awful lot of money and that if it were mine, I sure would want it back," Sammy thinks to herself as she 
listens to the woman's flustered and anxious conversation with the police (21). This moment of empathy compels Sammy to come forward, placing herself and her living situation at risk in order to give her testimony as an act of compassion toward the woman. Sammy approaches Gina, the woman who was the victim of the robbery, and Borsch, the officer who is in charge of the investigation. Sammy gives her eyewitness account, despite her previous convictions, motivated by a moment of compassion for a fellow human being and faith that even if her own relationship with the police is complicated, telling the police what she knows will ultimately help another person. In order to care for Gina - who, until this moment, is a stranger to Sammy - she relies on the principle that police are generally good, despite the danger they pose to her living situation. Sammy perceives that expressing care for Grams means avoiding police, while expressing care for Gina means trusting the police. This ironic tension highlights the necessity of contextual reasoning within an ethic of care while also emphasizing a complicated dynamic between care and justice ethics in which they can never be truly separated from one another.

This dynamic additionally highlights a sense of conflict between Sammy and government institutional forces that continues to be highlighted in Sammy's interactions with the police. While Sammy tries to give her testimony, Officer Borsch squints, interrupts, shakes his head, and gives Sammy no inclination that he is taking her account seriously. "I didn't like the way he was rolling his eyes and talking down to me," Sammy narrates. "He was treating me like a stupid little kid, and I'm not a stupid little kid" (22). Officer Borsch continues to disregard and dismiss Sammy throughout the story, even accusing her of falsifying evidence after she figures out how the thief was able to get into the Heavenly Hotel (116). Grams angrily offers to confront Officer Borsch herself after this accusation is made (she is, eventually, made aware of Sammy's situation), and Sammy defeatedly replies, "He won't believe you no matter what you say" (120). 
Disregarding Sammy isn't the only the way that Officer Borsch is failing in this investigation; when Sammy asks Gina if there has been any progress finding her stolen property, Gina is so convinced of Officer Borsch's incompetence that she replies, "No way. Not with that buffoon in charge" (83).

The conflict between Sammy and the police heightens as Sammy's official involvement in the case escalates, putting her living situation at risk - both her life itself and her housing. The hotel thief leaves a threatening note for Sammy in the Senior Highrise: "If you talk, you'll be sorry" (62). Mrs. Graybill finds the note and reports it to the police, claiming that Sammy sent it to her as a threat. This brings Officer Borsch to Grams' apartment, and Grams has to prove that Sammy doesn't live there while Sammy hides anxiously in Grams' closet (94-98). This brings Sammy's involvement with the police and the hotel thief to a new level of uncomfortable entanglement for Sammy, who feels unsafe because the hotel thief knows where she lives and has now issued a threat against her, and because the police have come close to discovering Sammy and Grams' illegal housing situation.

And so Sammy has several reasons for wanting the case of the burglary to be solved: she wants her new friend, Gina, to get back what was stolen from her, she's afraid of the thief's threatening note ("[I]t was scaring the oatmeal out of me" (62)), and she is afraid of the attention the whole situation has drawn to her grandmother's apartment. She has also entirely lost faith in Officer Borsch's ability to resolve this precarious situation; in fact, he has in many ways made the situation worse. If she wants to protect herself and her loved ones - which because of her inclination toward attachment, care, and relationships, she is compelled to do - Sammy cannot rely on the police to help or protect her. In response to this gap in the institutional authority of the police, Sammy resolves to solve the mystery herself. 
Thus, Officer Borsch's (mis)handling of the robbery highlights a gap in the police system as the robbery (a crime that is presented by the text as morally bad) remains unsolved and Sammy's living situation (a crime that is presented by the text as morally justified) grows ever more precarious. Ironically, a system that claims to protect the innocent and punish the guilty appears to be doing the opposite. Being aware of this gap places Sammy in a moral dilemma which is rooted in a conflict of care versus justice. Sammy does not hold a complete disregard for rules and principles, which signals that she is not a complete stranger to an ethic of justice. This explains why she initially places so much faith in the police at the beginning of the story: there is a fundamental principle in white, middle-class U.S. society that the police are trustworthy and exist to serve and protect the innocent, and despite Sammy's own unique living situation, she still has faith in the general principle of this institutional authority. As Sammy increasingly realizes that relying on the police is not actually going to serve her interests or those of her loved ones, she understands that the greatest act of care in this situation is for her to take on the role of sleuth and catch the burglar herself. Her motivation to become a sleuth is rooted in an ethic of care.

In the process of solving the mystery of the robbery, Sammy is faced with many opportunities to question the fundamental principles on which she has previously relied in making sense of the world, especially those principles that denote rules and authority as they are constructed by adults. This underscores the critiques the text makes against government institutions as aetonormative institutions. For example, when Gina tells Sammy that she once took her telescope to the roof of the mall to look at the stars, Sammy replies:

"The roof of the mall? How do you get up there?"

"Haven't you ever gone behind one of those 'Employees Only' doors?" 
"No..."

"They'll take you straight to the roof." Gina laughs. "And here I thought you were an anarchist" (86-87).

What Gina has encouraged Sammy to do in this conversation is to ignore the "Employees Only" signs at the mall, which are a marker of (adult) authority that Sammy appears to have always unquestioningly respected out of an innate regard for societal rules. These signs, Gina helps Sammy realize, are only a construct. When she elects to pass through the "Employees Only" door despite not being an employee (89), Sammy is not only disregarding the institutional and adult authority that the sign symbolizes, but she is also taking a new power unto herself - she is entering into a taboo space, a space reserved for adult authority figures, and claiming it as her own. Being on the roof of the mall gives Sammy a new view of the neighborhood that allows her to ultimately piece together the thief's identity and formulate her plan to catch him. This is especially significant given how many adults have access to this space but are not able to utilize it to the same effect as Sammy. It is ironic when Sammy, who does not yet belong to this world of adult authority, is able to use the tools of adults more effectively than the adults.

Despite this foray into what Gina sardonically refers to as anarchism, the next stage of Sammy's arc is not to reject all forms of authority and embrace full anarchy; she only does this to the extent that it allows her to solve the mystery, catch the thief, and protect her loved ones. Once Sammy and her best friend, Marissa, have laid the trap to catch the thief, Sammy urges Marissa to run straight to the police station while Sammy tries to lead the thief away from Marissa (147). The moment Sammy realizes that she's lost the thief, her first action is to find a way to call 911 and ask for help (148-49). She finally traps the thief in a dumpster, then comments: "I never thought there'd come a day when I'd be happy to see Officer Borsch, but let 
me tell you, I don't think I've ever been so relieved to see anyone in my whole life" (153). While critiques have been made about the police, and especially Officer Borsch, Sammy recognizes that she needs them to arrest the thief; without this final action, the case will not be closed. While Sammy's motivations are consistently rooted in a valuing of attachment, relational ethics, and responsibility that mark an ethic of care, she finds that the principled, rule-oriented approach which marks an ethic of justice can still, in some scenarios, help her to perform as one-caring to her cared-fors. ${ }^{5}$

\section{Alex Rider}

Similar to Sammy's circumstances, Alex Rider's living situation emphasizes a dialectic between separation and attachment. Alex's parents died in a plane crash when he was an infant, leaving Alex in the care of his last surviving relative, his uncle Ian. Although Ian is elusive ("Ian Rider was always traveling. A quiet, private man...”) his relationship with Alex is framed as a close one: "They had not been relations, they'd been friends" (Horowitz 3). As I mentioned in my analysis of Sammy Keyes: white, U.S. middle-class society promotes a fundamental principle that police are generally good and truthful. Alex's bond with Ian brings Alex to question this principle as he notices inconsistencies in the police's report of Ian's death. Motivated by his sense of responsibility toward his late uncle, Alex becomes a sleuth in order to challenge the authorities in government institutions that rely on principled justice ethics to obscure the truth of Ian's death and manipulate Alex.

${ }^{5}$ Coined by Nel Noddings in Caring: A Relational Approach to Ethics and Moral Education, the terms "one-caring" and "cared-for" describe the two parties that make up a caring relationship. These concepts will be further explored in chapter 3 . 
Stormbreaker opens with Ian's death, which, according to the police, was caused by a car accident. Alex's sense of closeness with his uncle is the reason he is able to sense the weak points in the police's story and suspect that, despite his belief that police are generally truthful, they are not being straightforward about Ian's death. Alex begins to connect the dots in the car on the way to the funeral with his housekeeper, Jack, who also expresses an innate trust that police are generally honest:

“The police said he wasn't wearing his seat belt." Alex turned to look at Jack.

She nodded. "Yeah. That's what they said."

“Doesn't that seem strange to you? You know how careful he was. He always wore his seat belt. He wouldn't even drive me around the corner without making me put mine on."

Jack thought for a moment, then shrugged. "Yeah, it is strange," she said. "But that must have been the way it was. Why would the police have lied?" (4-5)

The seatbelt is a minute detail, but Alex's sense of confidence in his relationship with Ian compels him to question the accuracy of the report he and Jack are given about Ian's death. Jack's question - "Why would the police have lied?" (5) - becomes Alex's first mystery to solve.

As Ian's funeral proceeds, Alex continues to feel a disconnect between his confidence in his relationship with Ian and the increasing sense that he is missing critical information about Ian's life. Alex wonders why he has never met any of the people from "the bank" who attend the funeral, and Alex is surprised when the vicar describes Ian as "a patriotic man": "His choice of words struck Alex as odd. Patriotic? That meant he loved his country. But as far as Alex knew, Ian Rider had barely spent any time in it. Certainly he had never been one for waving the Union 
Jack" (7). As these observations add up, Alex increasingly wonders whether he simply did not know Ian as well as he thought he did, or whether he is being purposefully misled regarding the circumstances of Ian's death. This concern is rooted in a dilemma of separation and attachment, as the separation of death substantially limits Alex's ability to reaffirm his bond with Ian. Alex is convinced of the latter when Alex and Jack return home from the funeral and Alex finds that:

[t]he door to [Ian's] office, which had always, always been locked, was now unlocked. Alex opened it and went in. The room was empty. Ian Rider had gone and so had everything else. The desk drawers, the closets, the shelves... anything connected to the dead man's work had been taken. Whatever the truth was about his uncle's past, someone had just wiped it out. (10)

When Ian's office is mysteriously emptied, Alex gains confidence in his theory that he is being purposefully barred from knowing the truth about Ian's death. As he revisits his previous observations in light of this most recent development, his convictions only grow stronger: Ian Rider hadn't been wearing a seat belt. But of course he had. Ian Rider had never been one to give lectures. He had always said Alex should make up his own mind about things. But he'd had this thing about seat belts. The more Alex thought about it, the less he believed it. A collision in the middle of the city. Suddenly he wished he could see the car. At least the wreckage would tell him that the accident had really happened, that Ian Rider had really died that way. (12)

Alex is experiencing a clash between two principles: the principle that police can generally be trusted to be truthful and the principle that Ian always wore his seatbelt. One of these principles has to be wrong, Alex reasons, and he is increasingly certain that it is the former. This tension 
additionally represents a clash between relationships: Alex cannot trust in his bond with Ian while also trusting in the integrity of the police.

In order to resolve this dissonance, Alex traces Ian's car to the junkyard it was sent to after the alleged accident. The cause of Ian's death becomes apparent when Alex sees the driver's side of the BMW, which is sprayed with bullet holes, confirming Alex's suspicions that Ian had not died in an ordinary car accident (16). He discovers no evidence as to whether Ian was wearing his seatbelt, but Alex deduces that Ian's cause of death was not related to seatbelt safety and that the police have clearly not given Alex the truth. "But why?" Alex thinks to himself. "Why kill a bank manager? And why had the murder been covered up? It was the police who had delivered the news that night, so they must be part of it. Had they lied deliberately? None of it made sense" (16). The BMW proves that the police have not been honest about how Ian died, eliminating the possibility that Alex can view the police as trustworthy. However, Alex's relationship with Ian still remains unaffirmed as he lacks an explanation for the cover-up. Alex continues to suspect that he is missing critical information about Ian's life, and he will not feel that he has affirmed his relationship with his uncle until he knows what that information is and the reasons behind the secrecy.

Alex is still in this mindset when he is later summoned by John Crawley, who represents himself as the person in charge of Ian's accounts at the "bank" that Ian had supposedly worked for. Once Alex reaches the bank, " $[\mathrm{H}] \mathrm{e}$ wondered if he was making a mistake, going in. If the bank had been responsible in some way for Ian Rider's death, it was always possible they had asked him here to arrange his own. But why would anyone from the bank want to kill him? He didn't even have an account there" (24). 
As Alex and Crawley move toward Crawley's office, Alex notices that Ian's office is right next door. Not seeing any other way to affirm his bond with Ian, Alex jumps from Crawley's window to Ian's. The course of events that follows soon brings him to a secret facility where he comes face-to-face with the head of MI6, Alan Blunt, and his second-in-command, Mrs. Jones. ${ }^{6}$ Blunt reveals to Alex that his uncle was not a banker who died in a car accident, but a spy who was killed while on a mission for MI6 (34). This knowledge allows Alex to reconcile the discordance he was feeling in his relationships with the police and with Ian: both the police and Ian have hidden information from Alex, but now that Alex knows the reason behind the deception, there no longer remains a dilemma of separation versus attachment. Alex feels a renewed sense of attachment to Ian and no longer feels a responsibility to pursue the matter further: the need for sleuthing is over, at least for the time being.

Now that Alex knows the truth about Ian, thus satisfying Alex's need to validate his relationship with his late uncle, Alex has no further interest in MI6 and is willing to do whatever Blunt requires of him to let the case come to a close: "You've brought me here because you don't want me to tell anyone what I know. Is that what this is all about? Because if it is, I'll sign the Official Secrets Act or whatever it is you want me to do, but then I'd like to go home." However, as Blunt tells Alex, "It's not quite as easy as that [...] [T] he fact of the matter is, Alex, that we need your help" (36). Ian's death was a signal that he was found out by the person he was investigating, and MI6 needs to send in a replacement agent who will defy all expectations of what a spy "should" look like; specifically, they want to send Alex. "After all," Blunt says, "who would suspect a fourteen-year-old boy of being a spy?" (43). The negotiations that follow

\footnotetext{
${ }^{6}$ No first name is provided for Mrs. Jones. Later texts reveal that Alan Blunt and Mrs. Jones are both code names passed down to every person who successively fills these roles.
} 
between Blunt and Alex continue to demonstrate a conflict between justice ethics and care ethics. In order to obtain Alex's consent, Blunt first appeals to Alex under the assumption that Alex, on a principle of patriotism, will appreciate an "easy" way to demonstrate his loyalty to England: "All we're asking you to do is to report back to us [....] That's all we're asking. Three weeks of your time [and ... a] chance to serve your country" (44). Yet Alex says no to Blunt's proposition. "I'm sorry?" Blunt asks, surprised. "It's a dumb idea," Alex responds. "I don't want to be a spy. I want to play soccer. Anyway, I have a life of my own" (44). Blunt is surprised that his attempt to appeal to Alex through justice ethics is ineffective, and quickly realizes that Alex will need to be coerced through alternative measures. Instead of manipulating Alex's (assumed) principle of patriotism, Blunt manipulates Alex's valuing of attachment and fear of separation: Blunt reveals that Ian left Alex his money and his house, but that it has been left in trust with the Royal and General (the bank which acts as MI6's public face) until Alex is twenty-one. Therefore, Blunt controls Alex's living situation and he intends to use that power to have Jack deported back to America and Alex sent to a boarding school - unless, of course, Alex consents to finish Ian's mission. If Alex refuses to accept the mission and accepts Blunt's consequences, Alex would be separated from everything and everyone he knows. Resentfully aware that his ethic of care is being used to manipulate him, Alex begrudgingly agrees to Blunt's terms: "Yeah. All right. It doesn't look like I've got very much choice" (46). The exploitative measures that Blunt takes to coerce Alex's consent foreshadow that Alex's conflict with authorities in government institutions is not over, and that MI6 will continue to be challenged throughout Alex's engagement with them.

After this conversation with Blunt, Alex becomes MI6's newest recruit, and their first adolescent spy. As I have described, a spy is not necessarily the same as a sleuth, but in Alex's 
case the two roles frequently overlap. This first part of Stormbreaker is heavily rooted in what I identify as sleuthing for the adolescent protagonist - a moral crisis caused by a critical gap in government and institutional authorities which forces the protagonist into a dilemma of separation versus attachment which is ultimately solved through sleuthing. Up until Alex is officially "recruited" as a spy, he is acting as a sleuth. For a time after this moment, Alex then acts as a spy rather than a sleuth. His directions are to report back to MI6 if he finds anything suspicious at Sayle Enterprises regarding an upcoming shipment of computers, at which point MI6 will be able to officially intervene and Alex will finally be allowed to go home. Alex follows the trail of information that Ian left behind at Sayle Enterprises, most notably finding a map that MI6 is unable to decode (109). MI6's inability to decode the biggest clue that Alex has so far uncovered symbolically emphasizes Alex's lack of confidence in MI6's ability to complete the mission without him. This is a further critique on this authority in government institutions that has already deceived and manipulated Alex to serve their own needs.

When Alex is given his briefing, he is also instructed to contact MI6 immediately if he sees Yassen Gregorovitch, a known assassin that MI6 suspects was hired to kill Ian: "We'll pull you out," Mrs. Jones tells Alex. "It doesn't matter how old you are, Alex. If Yassen finds out you're working for us, he'll kill you too" (70). Perhaps unsurprisingly, Alex does eventually encounter Yassen, which gives him liberty to contact MI6 and hand the responsibility of the mission back to them. However, the message from MI6 about being unable to decode the map is received at about the same time as Alex sees Yassen. Seeing Yassen is the final clue Alex needs to confirm that there is an important mystery to be solved at Sayle Enterprises, and he comes to this realization at the same time as he has this other realization about MI6's limitations. By the instructions he has been given by MI6, Alex could report that he has seen Yassen and be 
extracted from the mission, handing the responsibility of solving the mystery and stopping Herod Sayle's evil plan back to MI6. However, "Something was going on at Sayle Enterprises. [Alex]'d never forgive himself if he didn't find out what it was" (109). Even though the rules of the mission permit Alex to have himself pulled out at this point, he does not have confidence that MI6 will be able to complete the mission on their own. Although Alex is unsure at this point what Sayle's ultimate goals are or who, exactly, is endangered by them, Alex has concluded that something dangerous will happen if Sayle is able to complete his scheme. Handing the mission back over to the incompetent MI6 would equivocate complicity in Sayle's plans and in whatever harm occurs to other people as a result. Thus, Alex chooses to stay and see the mission through to the end, once again employing a method of moral reasoning that emphasizes an ethic of care more than an ethic of justice.

Although Alex's ethic of care is frequently emphasized by the text, he still finds that the principled, rule-oriented reasoning that marks an ethic of justice has a place in his sleuthing. For example, when Alex realizes that Sayle is planning to poison the children of England through a mass distribution of Stormbreaker computers, Alex (understandably) demonstrates an unquestioned principle that killing children is bad. He also is shown several times throughout the text to operate under the principle that truth is generally good, desirable, and worth pursuing even at great cost. These ideologies are unquestioned in the text (although not uncontextualized), which indicates their principled nature; Alex leans on them, employing the type of reasoning that Ruddick might correlate with a traditionally patriarchal mode of reasoning. But these principles serve Alex in tandem with his ethic of care, allowing him to respond effectively to the moral crises that MI6's faults place him in, crises that can consistently be traced back to a dilemma of separation and attachment. 


\section{Conclusion}

What Sammy and Alex both demonstrate is an inclination toward an ethic of care without a complete rejection of an ethic of justice. These negotiations are reflective of how Held describes care and justice as interlocking spheres:

Care is probably the most deeply fundamental value. There can be care without justice [.... There can be no justice without care, however, for without care no child would survive and there would be no persons to respect [...] But although care may be the more fundamental value, it may well be that the ethics of care does not itself provide adequate theoretical resources for dealing with issues of justice. Within its appropriate sphere and for its relevant questions, the ethics of justice may be best for what we seek. What should be resisted is the traditional inclination to expand the reach of justice in such a way that it is mistakenly imagined to be able to give us a comprehensive morality suitable for all moral questions. (17)

Here I have shown both Sammy and Alex negotiating care and justice in such a way that resists or challenges the "traditional inclination" to treat an ethic of justice as universally applicable. This "tradition," as scholars such as Ruddick and Collins have pointed out, is rooted in age-old systems of oppression.

These traditions are the foundations upon which authorities in government institutions are constructed; the legal justice system is built on a greater system of oppression that values an ethic of justice over an ethic of care. The limitations of such a system are highlighted in sleuthing stories such as in the examples of Sammy and Alex, who, as this chapter has demonstrated, are each placed in a state of moral crisis as a result of this system's limitations. Sammy and Alex each resolve this crisis through "sleuthing": by taking actions that are unsanctioned by 
authorities in government institutions in order to fill a gap that those same authorities cannot or will not fill themselves. In their employment of an ethic of care, Sammy and Alex challenge not just individual actors within these institutions, but also the fundamental structures of these institutions that problematically privilege justice ethics over care ethics. In the next chapter, I will further consider how this moral framework is implicated by the adolescent sleuth's intersecting racial, gendered, and age-based subjectivities. 


\title{
CHAPTER II: “THE PRIVILEGE OF SLEUTHING”: SUBJECTIVE POWER IN SLEUTHING
}

\section{STORIES}

\begin{abstract}
"After all, who would suspect a fourteen-year-old boy of being a spy?"
- Alan Blunt, Stormbreaker (Horowitz 43)
\end{abstract}

Both Sammy Keyes and Alex Rider are teenage protagonists who are hailed to fill a gap that the (adult) authorities in government institutions either can't or won't fill themselves. Confronting this gap places each of these protagonists in a moral crisis which is rooted in the dilemma of separation versus attachment described by Carol Gilligan. Both Sammy and Alex resolve this crisis through sleuthing. For Sammy and Alex, sleuthing is a moral action taken in response to a noticed flaw in authorities in government institutions. As I established in the previous chapter, Sammy and Alex each demonstrate an inclination toward an ethic of care while acknowledging the occasional use of an ethic of justice, and each engages in conflicts that emphasize the potential benefits and risks of each of these ethics.

This chapter focuses on the implications of sleuthing as an exercise in subjective power and privilege. How and why Sammy and Alex decide to and are enabled to become sleuths is rooted in each character's respective intersecting subjectivities, particularly those of age, gender, and race. ${ }^{7}$ These dynamics are further apparent in the 2016 tabletop roleplaying game BubbleGumshoe: A Teen Detective Story Game created by Emily Care Boss, Kenneth Hite, and Lisa Steele in which the players serve together as a group of teen sleuths in order to solve a

${ }^{7}$ This is not to say that additional considerations such as class, ability, etc. are not at play or that they aren't worth considering, but that age, gender, and race are the focus of this particular analysis. 
mystery. Sammy negotiates her subjectivity as a thin, white adolescent female with privilege, Alex negotiates his subjectivity as a white adolescent male, and BubbleGumshoe places an inappropriate emphasis on race in its guidelines on character creation. As I will demonstrate in this chapter, sleuthing is an exercise of subjective power and privilege which enables the (white) adolescent sleuth both to challenge systems of oppression and to use those systems to their own advantage.

\section{Sleuthing as a Counternarrative to Aetonormativity}

As Maria Nikolajeva explains in Power, Voice and Subjectivity in Literature for Young Readers, the great irony of children's literature is that it seeks to "both [...] empower the child and $[\ldots]$ protect him from the dangers of childhood" (20). This, Nikolajeva says, "is the essence of aetonormativity in a nutshell" (20). Problematizing this tendency further, Nikolajeva explains that, "In terms of social conditions, in real as well as in fictive worlds, adults are and will always be superior to children. Here, power hierarchy is non-negotiable, unlike other heterological situations (gender, class, sexual preference), and power is inevitably self reproducing" (203). Aetonormativity thus becomes especially relevant to the analysis of adolescent sleuthing stories. As I have previously cited, Roberta Seelinger Trites asserts the following:

Adolescents have power that becomes institutional power as they (necessarily) engage in the social forces that simultaneously empower and repress them [....] All YA novels depict some postmodern tension between individuals and institutions. And the tension is often depicted as residing within discursive constructs. Once protagonists of the YA novel have learned to discursively negotiate their place in the domination-repression chain of power, they are usually depicted as having grown. (52) 
Not only do adolescent sleuthing stories emphasize the "tension between individuals and institutions," but they connect this conversation with the tension between adolescents and adults. While Trites identifies this as a defining feature of adolescent literature in a broad sense, adolescent sleuthing stories uniquely highlight this tension because they are always engaged specifically with some aspect of government authority (usually law enforcement); always contain some critique of that institution; and always depict an adolescent character who, as Trites says about all adolescent protagonists, has "power that becomes institutional power as they (necessarily) engage in the social forces that simultaneously empower and repress them."

Sammy Keyes and Alex Rider each leverage their subjective power as they "negotiate their place in the domination-repression chain of power" in their engagement with and against adult agents of government authority.

In a particularly poignant scene, Sammy tries to give her eyewitness account of the hotel robbery to Officer Borsch in order to aid the police in their institutionally-designated imperative as law enforcement to catch the thief. Officer Borsch refuses to accept her testimony because of her age and gender, leveraging his status as an adult male over Sammy's status as an underage female. However, Officer Borsch is also portrayed as being overweight, which gives Sammy one form of institutional privilege over him. Sammy responds to Officer Borsch's ageism and sexism by leveraging her thin privilege in order to assert some degree of power over Officer Borsch:

Well, let me tell you, I didn't like the way [Officer Borsch] was rolling his eyes and talking down to me. He was treating me like a stupid little kid, and I'm not a stupid little kid. So when he sighs and says, "Could you at least tell me, was he skinny or fat?" I point to Tall 'n' Skinny and say, "Well, he wasn't as skinny as him..." then point to the Borschman, “... and he sure wasn't as fat as you.” 
The lady busts up, but Officer Borsch doesn't think it's too funny. His neck gets kind of red and he puts his face right next to mine. "Look, little girl, we've had five burglaries in this vicinity in the past two weeks. We don't have time for your wisecracks. If you know something, tell us. If you don't, or you're just making all this up, then go home to your mommy and let us do our work." (Van Draanen 22-23)

In this interaction, the tension between Officer Borsch as an adult male police officer, and Sammy as a teenage girl, is palpable. Officer Borsch is using his physical embodiment by "rolling his eyes," "talking down," and putting his face "right next to" Sammy's in order to intimidate her. He asks for her testimony, which she has been trying to give, but his physical and verbal cues - i.e., "little girl" and "go home to your mommy" - indicate that he will not take seriously whatever information she does offer. Sammy acknowledges his power over her by dignifying his demeaning questions with a response, but she makes sure to deliver that information dripping in sarcasm and fatphobic insults.

Sammy's choice to fat-shame Officer Borsch in response to his own commentary on her marginalized subjectivities as female and adolescent is reminiscent of a phenomenon Paolo Friere discusses in Pedagogy of the Oppressed:

[A]lmost always, during the initial stage of the struggle, the oppressed, instead of striving for liberation, tend themselves to become oppressors, or "sub-oppressors." The very structure of their thought has been conditioned by the contradictions of the concrete, existential situation by which they were shaped. Their ideal is to be men; but for them, to be men is to be oppressors. This is their model of humanity. (45-46) Sammy's instinctive reaction to Officer Borsch's commentary on her age and her gender is to comment on his body. While this has the rhetorical effect of subverting Officer Borsch's use of 
his own physicality as a large adult male into an insult, thus undercutting that tool of intimidation which he uses against her, it also contributes to fatphobic ideologies and the marginalization of fat bodies. Sammy leverages her thin privilege against Officer Borsch's adult male privilege; or, in other words, Sammy acts as one kind of oppressor in order to challenge another kind of oppressor.

Sammy's denigration of Officer Borsch illustrates that Friere's theories of oppression can become complicated in the context of aetonormativity. As this scene demonstrates, additional subjectivities - gender and body size being only two examples - are always at play in interactions between adults and teenagers, so it is difficult to sort through these dynamics in order to focus specifically on the aetonormative dynamics at play. To do so, we must have a clear idea of which behaviors in a given interaction are strictly "adult" behaviors and which are strictly "adolescent" in nature. But these understandings of childhood, adolescence, and adulthood are all, like other subjectivities, socially constructed (as Carrie Hintz and Eric L. Tribunella describe in detail via their "models of childhood" in Reading Children's Literature: A Critical Introduction; pp. 13-29). Therefore, like gender and other subject positions, claims about what constitutes "adulthood" and "adolescence" must similarly be considered not only in terms of inherent traits according to age, but also in terms of traditional associations a particular society (in this case, contemporary U.S. society) has made in defining these subjectivities. Taking Gilligan's and Trites' claims of adolescence in conversation with each other, I am considering adolescence as a time between childhood and adulthood marked by specific kinds of negotiations of power and morality; this transitional period is complete once these negotiations have settled into a relatively consistent rhythm that adheres to normative expectations of power and morality. This poses the question of whether adolescents, as the oppressed group, are able to 
transcend oppression without becoming the oppressors. While the biological reality of aging is inevitable (except in the case of death), conceptualizations of adolescence and adulthood are culturally constructed and do not necessarily need to be marked by an assimilation into normative (repressive) power structures. In this interaction between Sammy and Officer Borsch, Sammy resists some repressive power structures while actively weaponizing other repressive power structures for her own benefit.

What adolescent sleuthing stories specifically have to offer to aetonormativity discourse is that these stories explicitly interrogate the authority of institutions that are constructed and enforced by adults. Sammy is able to do what Officer Borsch does not, which is to capture the hotel thief; this raises the question of what it is, exactly, about Sammy that enables her to do this. In the case of the hotel thief, the novel suggests that the very liminality of adolescence is what positions Sammy to do what Officer Borsch cannot. This suggestion is made via the recurring theme of subverted expectations which is amplified throughout the text.

The themes of liminality and subverted expectations begin with Sammy's living situation. Sammy is not meant to live with Grams permanently (as later books clarify, Sammy is only meant to stay with Grams until her mother comes back from Hollywood) which means that, in addition to discursively occupying the liminal space of adolescence, Sammy is physically occupying the liminal (for her) space of Grams' apartment. Sammy's age-dependent subjectivity bars her from living anywhere else, so she has to devise manipulative tactics to protect herself and Grams. One problem is that the only "official" means in and out of the Highrise is the lobby, which is overseen by the property manager. The property manager sees everyone who passes through the lobby, and Sammy needs him to believe that she is not sleeping in Grams' apartment every night. Since the manager expects this to be the only way in and out of the building, Sammy 
jams the fire escape door and uses that as her secret passage in and out of the building; this method takes advantage of the loophole created by the manager's expectations. Similarly, the manager at the Heavenly Hotel also believes that the lobby is the only way in and out of the hotel, and one of the biggest curiosities of the robbery is that the manager has no record of anyone unexpected being in the lobby during the time of the crime. Nobody can figure out how the thief was able to get in and out of the hotel unseen. Because of Sammy's experiences with getting in and out of the Senior Highrise, she thinks to check the fire escape door at the Heavenly Hotel, which, sure enough, is jammed with a paper napkin (110). Sammy's liminal living situation, which is implicated by her adolescence, grants her unique access to a perspective that is necessary in order to figure out how the thief was able to enter and exit the hotel unseen.

Although Sammy has solved how the thief was able to access the hotel unseen, the thief's identity remains unknown. The continued theme of connecting subverted expectations with liminality and youthfulness helps Sammy toward this final conclusion. Sammy's friend Hudson is renting his converted garage to a man who, to Sammy, looks like an accountant but who turns out to be a popular radio DJ; upon realizing this and in a moment of foreshadowing, Hudson says, "My dear, things are not always what they appear" (127). Sammy recalls these words later when she and Marissa celebrate a victory over a school bully with a couple of ice cream cones a scene heavily coded as normatively youthful. As Sammy looks at the napkins wrapped around her cone, she realizes that they are the same type of napkin that was used to jam the fire escape door at the Heavenly Hotel. This leads her to conclude that the hotel thief is actually Oscar, the local ice cream man:

[T]he longer I stare at the napkins the colder I feel, until finally my whole body is shivering. 
I whisper, “No...it can’t be," but Hudson's voice keeps echoing through my brain: "My dear, things are not always what they appear." And the more I think about it, the more I know.

I know who the hotel thief is. (139)

Although Sammy previously believes Oscar to be blind, and therefore unable to be the thief, the napkins bring Sammy to recall something she had seen the day that she first explored the roof of the mall: "I looked down the street $[\ldots]$ and sure enough, there's Oscar $[\ldots]$ cleaning his [sun]glasses with a hanky" (91). After Sammy connects the napkins in the doorjamb to the napkins Oscar carries in his ice cream cart, Sammy asks Marissa, "How would a blind person know if his [sun] glasses were clean or not?" (146). In short, "Oscar" turns out to be just one of the many aliases the thief (who is, in actuality, sighted) ${ }^{8}$ uses to get around town unnoticed, a disguise that takes advantage of stereotypes about disabled people (i.e., a perception of disabled people as innately innocent) to construct a set of expectations that can then be manipulated to enable his career of crime. Sammy does not initially consider Oscar to be a viable suspect because the thief looks directly at her during the robbery, which indicates that the thief is a sighted person. The recurring theme of subverted expectations, which are continually linked to her own experiences existing within discursively and non-discursively liminal spaces, leads Sammy to question her initial assessment of Oscar and realize his ruse.

This flexible thinking stands in stark contrast to Officer Borsch, who is not presented as embodying any liminal space and who therefore struggles to second-guess his own assumptions and biases throughout the text. Officer Borsch makes negative assumptions about Sammy that

\footnotetext{
${ }^{8}$ The appropriation of disability by the villain of the story is worth noting, although it is beyond the scope of this thesis.
} 
are rooted in sexist and aetonormative stereotypes and refuses to question his own biases even if doing so would help him catch the thief. Officer Borsch's unwillingness to question his own expectations becomes his greatest barrier in his efforts to solve the case. Sammy knows that Officer Borsch is not willing to listen to her conclusions about the case, even once she is confident that she has discovered the thief's identity: "What I probably should have done was call the police. Or at least go over to the station and tell them what I thought. Trouble is, they would've called in Officer Borsch and I wouldn't been stuck talking myself blue in the face to someone who wasn't about to believe me. Not unless I could clobber him over the head with some proof" (143). Officer Borsch is stubbornly committed to his limited and prejudiced perceptions of Sammy, and Sammy knows that the only way to convince Officer Borsch to consider her theory is to provide proof so undeniable that even he will not be able to dismiss it. At this point that Sammy decides to catch the thief herself and deliver him to the police because what proof could be more undeniable than that?

The irony of this contrast between Sammy and Officer Borsch underscores the critiques being made against the police as an aetonormative institution of authority. Because of Sammy's liminal positioning, she is able to solve the case and catch the thief, and her adolescence is key to her liminality. Officer Borsch is anything but liminal - he adamantly resists change and uncertainty at any cost - and because of his static nature, he is unable to solve the case.

Additionally, Sammy's decision to catch the thief brings me back to Friere's pedagogy of the oppressed. As I will discuss in more detail later in this chapter, law enforcement has a long history of acting as a mechanism of oppression. Sammy is oppressed because of her age and her gender. In order to challenge the prejudices placed upon her because of her age and gender, Sammy takes on the responsibility of law enforcement herself, opting to do the work of the very 
institution that she is critiquing. In acting within a role of law enforcement, Sammy takes on the role of oppressor to overcome the ways in which she is oppressed by this system.

In contrast to how Sammy's gendered subjectivity presents an obstacle to sleuthing, Alex's subjectivity as male plays an advantageous role in how he negotiates the various power tensions at play throughout the text. For example, the alias that MI6 assigns Alex to incorporate him organically into Sayle Enterprises is that of Felix Lester, another fourteen-year-old boy who won a competition in a computer magazine - a "young chap who's apparently a bit of a whiz kid when it comes to computers" (42). MI6 grants the real Felix Lester a holiday in Florida so that Alex can take his place at Sayle Enterprises (43). While the text presents it as a convenient coincidence that Alex happens to fit the description of the person that Herod Sayle is expecting, this also feeds into a cultural narrative that boys are expected to be good with computers, thus implicitly reducing the amount of suspicion around Alex's alias. Generally, Alex's male privilege goes unexamined and unchecked in the text.

Although Alex does not suffer the gender discrimination that Sammy faces, his positionality as an adolescent similarly acts as a double-edged sword as he engages with and against MI6. On one hand, his age is the reason that he makes such an effective spy:

"We can't just send in another agent," Mrs. Jones said. "The enemy has shown his hand. He's killed [Ian] Rider. He'll be expecting a replacement. Somehow we have to trick him."

"We have to send someone in who won't be noticed," Blunt continued. [....] "You [Alex] shouldn't be in any danger. After all, who would suspect a fourteen-year-old boy of being a spy?" (42-43) 
This assessment proves several times to be true. For example, when Alex is caught at Sayle Enterprises in a restricted area, he uses his age to his advantage to trick the guard: "'I'm staying with Mr. Sayle,' Alex said. He stared at the gun. 'Why are you pointing that thing at me? I'm not doing anything wrong.' He sounded pathetic. Little boy lost. But it had the desired effect. The guard hesitated, slightly lowering the gun. At that moment Alex struck" (140). In this example, Alex manipulates expectations of innocence ("little boy lost") to subvert the power dynamic and gain the upper hand against the guard.

Alex uses his age as an asset several times throughout his mission (and his gender - note that while Alex is presumed innocent by the guard, Sammy is presumed by Officer Borsch to be untruthful and attention-seeking), yet his age is also what makes him vulnerable to exploitation. With Ian dead and his affairs left in the control of MI6, Blunt is able to threaten Alex into becoming his teenage spy. When Alex initially refuses to be sent to Sayle Enterprises, Blunt demonstrates his ability to punish Alex for his noncompliance:

"Like it or not, Alex, the Royal and General is now your legal guardian [....] Ian Rider has, of course, left the house and all his money to you. However, he left it in trust until you are twenty-one. And we control that trust. So there will, I'm afraid, have to be some changes. The American girl who lives with you [....] Her visa has expired. She'll be returned to America [....] Unfortunately, you have no relatives who would be prepared to look after you, so I'm afraid that also means you'll have to [....] be sent to an institution. There's one I know just outside Birmingham [....] Not a very pleasant place, but I'm afraid there's no alternative."

"You're blackmailing me!” Alex exclaimed.

"Not at all." 
"But if I agreed to do what you asked...?"

Blunt glanced at Mrs. Jones. "Help us and we'll help you," she said. (45-46)

Blunt's use of coercive force to manipulate Alex frames Alex's feelings about being a spy through the remainder of the text. Later, once Alex has completed the mission and finally returns home, he thinks: "Blunt had forced him into this. In the end, the big difference between him and James Bond wasn't a question of age. It was a question of loyalty. In the old days, spies had done what they'd done because they loved their country, because they believed in what they were doing. But he'd never been given a choice. Nowadays, spies weren't employed. They were used" (187). This observation, although appearing to be generalized to all spies, is of course specific to Alex's own experiences; given allusions to Ian's paycheck and the interactions Alex has at a training camp with several adults who have consented to a career as a spy, the only spy being blatantly exploited is Alex, and it is his adolescence that makes him vulnerable to it. The presence of other white male spies within MI6 whose subjective power only differs from Alex on the basis of age emphasizes that Alex's age is what ultimately makes him vulnerable to Blunt's manipulations.

As I described in the previous chapter, Alex eventually reaches a point in the mission in which, according to the instructions he was given during his briefing, he should contact MI6 to be brought home. This moment occurs after he has seen Yassen Gregorovitch, the assassin who killed Ian, and after he receives the message from MI6 that they are unable to decode the map that Alex had found in Ian's old room at Sayle Enterprises (109). Having developed his own concern for the situation and lost confidence in MI6's ability to resolve said situation themselves, Alex decides to take upon himself the responsibility of stopping Herod Sayle. 
Just like Sammy has to step into a role that should have been fulfilled by Officer Borsch, Alex also finds himself taking on a role that is typically ascribed to adults. Even as these adolescent sleuths find themselves in a conflict against the (adult) government authorities of Officer Borsch and MI6, they also find themselves stepping in to fill the role that these authorities are meant to fulfill. This poses a counternarrative to the aetonormative ideologies that are foundational to these institutions while also validating the very purpose for which these authorities exist. While Sammy and Alex each overcome their individual oppression in challenging these oppressive institutions, their success is marked by stepping into the role of the very people who have individually enacted that oppression against them. This framing suggests that it is the individuals within these institutions that are the source of oppressive practices, rather than viewing oppression as systemic.

\section{"The Privilege of Sleuthing": Historical Trends of Gender and Race in Sleuthing Stories}

While I have identified sleuthing stories to be broadly marked by a conflict with any form of authority in government institutions, what we see in the cases of Sammy and Alex, and what I suspect is frequently the case, is a conflict specifically with law enforcement. Sammy and Alex are both oppressed by these authorities, Sammy by her local police and Alex through MI6. In highlighting this aetonormative oppression, these narratives critique these institutions. Yet even as Sammy and Alex are critical of these authorities, they also take it upon themselves to fill the role that these authorities are meant to fill so that they can catch the bad guy and save the day. Even as Sammy and Alex reject these institutions of law enforcement, they are also, ironically, choosing to adopt the role of law enforcement themselves. For Sammy and Alex, the act of becoming a sleuth is both a rejection of the oppressor and an act of becoming the oppressor. This 
reaction to a noticed gap in law enforcement is clearly connected to subjective power and the privilege(s) granted therein. The subjective privilege adolescent characters hold is critical to how and why they might become a sleuth, if they become one at all.

In Hard-Boiled Masculinities, Christopher Breu traces how the iconic detective is integrally rooted in constructions of white masculinity, particularly constructions of whiteness in opposition to blackness and masculinity in opposition to femininity: "A primarily, though not exclusively, white conception of male identity, hard-boiled masculinity was surreptitiously modeled on an understanding of black masculinity, as vitally and violently primitive" (2). Additionally, "Frank Krutnick [...] theorizes the emergence of the noir tough guy as part of the 'phallic order' in reaction to a postwar crisis in masculinity precipitated by the growth of the female workforce during the war and the challenges of adjustment for men returning home from the front" (3). Breu argues that as constructions of white masculinity have changed over time in Western culture in response to changing conceptions of people of color and of women, ${ }^{9}$ the iconic detective has reflected these changes.

The emergence of the girl sleuth provides one of the most well-known counternarratives to the hard-boiled male detective. In The Girl Sleuth: A Feminist Guide, Bobbie Ann Mason connects the rise of the girl sleuth with feminist movements. "Where would women's liberation be," Mason asks, "without Nancy Drew and Judy Bolton and Beverly Gray and Cherry Ames?" (6). Scholars frequently point out the correlation between the first Nancy Drew books in 1930, just ten years after the $19^{\text {th }}$ Amendment was ratified in 1920, and an increasing rise in political discontent among middle-class white women. As Caroyln Stewart Dyer observes: "The women who were perhaps most affected by the experience of reading about an independent, self-

\footnotetext{
${ }^{9}$ Though, obviously, these two groups are not mutually exclusive.
} 
confident, successful girl were those who grew up in the late 1940s and 1950s in the United States, when there was great pressure on girls and women to devote themselves to preparing to be perfect wives and mothers" (Dyer and Romalov 6). Yet, like Breu identifies for the white male detective, these early girl sleuths were confined to the parameters of normative white femininity, which, like white masculinity, relied on conceptions of minoritized individuals as inferior. With tongue in cheek, Mason writes: "[U]ndesirable characters are automatically associated with minority groups. But that's where the mystery is, of course. Mystery always lurks in wild, uncivilized, or foreign landscapes that threaten to spill over. Solving a mystery is like tidying. You can't have a perfectly laundered neighborhood as long as uncouth strangers are hanging about!" (21-22). Even though the emergence of the girl sleuth was radical for white women in that it provided a counternarrative to the traditionally masculine sphere of detective fiction, Mason's account highlights several problematic caveats in terms of race, class, and immigration.

First, the girl sleuth's adventures had to be justified as fitting within the realm of what might be considered "women's work" i.e., what Mason identifies as "tidying." Even the first Nancy Drew installments, which by today's standards would be considered very conservative, were considered radical for their time; as Mildred Wirt Benson, the first Nancy Drew writer, recalls: "Mr. Stratemeyer expressed bitter disappointment when he received the first manuscript, The Secret of the Old Clock, saying the heroine was much too flip and would never be well received" (Dyer \& Romalov 62).

Second, this "tidying" was always represented by the capturing of a villainous character, typically characterized as a minoritized individual, representing a victory of (what we now identify as) white supremacist heteropatriarchal ableist domination. Mason is particularly critical 
of the Bobbsey Twins in her descriptions of these problematic tropes: "Models of authority are insisted upon in the Bobbsey Twins series, not only through obvious sexism but through redwhite-and-blue patriotism and through extensive racism" (38). Furthermore, "The Bobbsey hierarchical world view is paradoxically a slave mentality, flagrantly Christian and American. In order to be free, you must worship. In order to be a winner, you must serve higher authorities, and winning means ascending the scale so that others are your slaves: step on others to get to the top, be a status seeker" (45). To be a sleuth means to draw a line between the "good guys" and the "bad guys." This line is a construct and therefore shifts to match the era, but these shifts are typically at the expense of reinforcing a hierarchy of power and privilege. In Mason's analysis of the Bobbsey Twins, she notes the explicit racism that is foundational to the books (particularly the early editions); for example: " $\mathrm{G}^{*}$ psies ${ }^{10}$ violate everything a Bobbsey stands for [.... The Bobbseys go to Blueberry Island for a friendly family vacation and are plagued to death by sneaky G*psies who steal their dog and cat" (42). This is just one of many examples Mason provides of non-white characters being presented as suspicious, violent, and always inferior to whites in the Bobbsey Twins series. The Bobbsey Twins, despite their youth and the inclusion of girls in their group, are able to enter the domain of sleuthing because they enforce the oppressive structures of white supremacy. Even though the emergence of the (white) girl sleuth correlates with the women's suffrage movement and is therefore integrally linked with women's rights, it is clear that the (white) girl sleuth also has a clear history of leveraging her whiteness to gain access to a white man's realm at the expense of others who are more marginalized than herself. Like the women's suffrage movement, the genre of the girl sleuth has historically centered the

\footnotetext{
${ }^{10}$ While Mason's 1975 text uses this term in full, I have modified how it is represented here to highlight that the term is now recognized as a racial slur.
} 
rights of white women while neglecting to also advocate for women of color. In other words, the girl sleuth has historically reinforced her oppressive role within white supremacy in order to overcome her oppressed role within patriarchy.

Interestingly, the rise of the girl sleuth and her "tidying" correlates with another major moment in American history: racial desegregation and the public beginning of the civil rights movement in the 1950s. As legal institutions became increasingly unable to (explicitly) enforce racism and communities became decreasingly segregated, the "need" for unofficial or unspoken methods of enforcing racism in white communities grew. The (white) girl sleuth got her foothold in the dominant discourse by proving that she was able to "tidy" the neighborhood of "wild, uncivilized, or foreign" entities, and was therefore worthy of gaining access up the ladder of white supremacist heteropatriarchal ableist domination. In proving that she could act within a certain parameter of the status quo, white women were able to gain, as Mason calls it, "the privilege of sleuthing" (49).

There remains today a noticeable lack of sleuths of color (regardless of age). Part of this is certainly a result of editorial erasure, as Sarah Weinman writes about in "The Case of the Disappearing Black Detective Novel.” But as Otto Penzler writes in the introduction to the anthology Black Noir: Mystery, Crime, and Suspense Fiction by African-American Writers: A nation's government, in order for detective stories to flourish, needs to be a relatively democratic one. Under dictatorial and repressive regimes, it is the police themselves who are regarded by much of the citizenry as villainous, not as the source of relief from fear and injustice $[\ldots .$.$] As the enemy, then, it is hardly likely that fiction would be created in$ which these figures would serve as the righteous heroes who would protect society from murderers, robbers, and other criminals [.... While many novels and short stories by 
black Americans had been published during the twentieth century, very few were detective novels. Many blacks saw the police as adversaries whose job it was to maintain the social status quo by beating them into submission. Therefore, just as nondemocratic societies failed to produce detective fiction, so did the black community. (xii) There are some exceptions to this - Penzler is writing, after all, for a collection of mystery fiction written by African-American writers - but he articulates an explanation for the lack of sleuths of color in the American literary tradition that is rooted in institutionalized racism. Although we have police, lawyers, and federal agents of color, the relationship between institutions of law enforcement and people of color remains complicated by institutionalized racist practices such as racial profiling and police brutality. While white protagonists such as Sammy and Alex may be comfortable stepping into the role of law enforcement, protagonists of color have good reason to be more hesitant.

As uncommon as the sleuth of color is in general in literature, the adolescent sleuth of color is even more obscure. In fact, in the roleplaying game BubbleGumshoe: A Teen Detective Story Game, players are encouraged to eliminate racism in the process of worldbuilding and character creation. This instruction is referring to a common practice in roleplaying games, in which players can decide whether or not the world of the game will include racism. The character creation process includes establishing a character's relational network beginning with their Class, Clique, and Club. For example, "Rich Kids" can be used as either a Class or a Clique. However, "In campaigns or settings foregrounding racial tensions, a minority Sleuth's race might be her Class or her Clique. Players should decide if that's a game they want to play before you define your Sleuth by her race" (34). Considerations such as gender and class receive no such cautionary advice in this text; in fact, BubbleGumshoe even sets the "girl sleuth" as the 
norm: "[T]he default pronoun in the BubbleGumshoe rules set is 'she," the instructions explain. "From Nancy Drew to Veronica Mars, the iconic teen sleuth is gendered female, in much the same way, perhaps, that the iconic armored knight is gendered male" (5). Yet while gender is emphasized in the structure of the game, it is not associated with Class or Clique, suggesting that social networks are implicated by race but not by gender. The advice the text provides to guide players around race is far more cautionary than any of the advice pertaining to other facets of character creation. This places an emphasis on racial tensions while de-emphasizing the potential for tensions based on other marginalized positions. This normalizes other forms of diversity while placing a disproportionate amount of forewarning on the potential for racial diversity. Sammy Keyes and Alex Rider are both critical of law enforcement, but their whiteness enables them to respond to these critiques through sleuthing. Even the most unpleasant scenarios that Sammy and Alex encounter through each of their stories would be dramatically heightened if the protagonist were of color. Although Sammy and Alex are oppressed by these legal authorities for their age (and, as I have described, Sammy is also implicated because of her gender), they are able to navigate around (some of) this oppression because of the other privileges they hold. For example, Alex's nemesis Herod Sayle is an immigrant of color; while Sayle's villainy is explained to be a vengeful response to his poor treatment as an immigrant of color, thus positioning Sayle as a victim of racism and xenophobia, this structure therefore contributes to the narrative of fear and suspicion surrounding this marginalized group that have contributed to systemic violence against people of color. Sammy Keyes' hotel thief pretends to be blind though he is not actually disabled; this appropriation of disability risks casting disabled people as suspicious or untrustworthy. Although Sammy and Alex are marginalized in some ways, their narratives follow the problematic "tidying" trope of the (white) girl sleuth who 
climbs the latter of institutional oppression by stepping on the backs of those less privileged than herself.

For Sammy and Alex, the act of sleuthing is a way of symbolically taking on the role of the oppressor for themselves. While aetonormativity is the primary source of tension here, this is not an unfathomable reach for these characters: they will, after all, eventually be adults themselves. For the adolescent sleuth of color, however, this dynamic is more complicated: certainly, they will also age biologically into adulthood, and they may even go into a career in law enforcement, but they will never be able to gain white privilege. The white adolescent sleuth and the sleuth of color will eventually outgrow their age-dependent oppression; the sleuth of color, however, will never be able to escape racial oppression without complete systemic reform. White girl sleuths were able to leverage their whiteness in order to earn a place in the masculine realm of detective fiction, so what will sleuths of color be expected to leverage in order to break into this white-dominated genre?

\section{Conclusion}

As I have noted previously, feminist ethics of care developed out of Gilligan's research on how gender correlates with different kinds of ethical reasoning. This emphasis on gender, particularly Gilligan's reminder that these correlations are rooted in how gender roles are encultured rather than implicit, was a challenge to patriarchal assertions about "rationality" and morality that has historically oppressed women in Western society. While an ethic of care is not inherently part of what it means to be a woman any more than an ethic of justice is inherently part of what it means to be a man, these two ethics have developed in Western society under a premise that (1) greatly indoctrinates women into an ethic of care and men into an ethic of 
justice, and (2) valorizes an ethic of justice as superior to an ethic of care. A patriarchal society relies on such a system in order to keep gender oppression intact.

As Patricia Hill Collins and Magnet, et al., point out, these ideologies have evolved to justify and sustain not just gender oppression, but all forms of oppression. Expectations of care and justice are problematically delineated in our society to uphold systems of oppression. The roles that care and justice play in this system continue to be used (1) to assign the expectation, responsibility, and labor of care to the most marginalized individuals while assigning the expectation, responsibility, and labor of justice to the least marginalized individuals; (2) to value justice ethics as implicitly superior to care ethics; and (3) to consider the resulting patterns of behavior not as a result of enculturation, but as a justification for keeping the systems of domination and oppression in place.

The girl sleuth has used her whiteness to buy her way into the sphere of detective fiction, which has historically been the domain of white men. In doing so, she has had to consent to the labor of sleuthing as a labor of care. The adolescent sleuth, similarly, has to buy the "privilege of sleuthing" at the cost of complicity with a system that, among other things, benefits from the exploitation of young people. Adolescent sleuthing stories are critical of authorities in government institutions, and the ability to respond to these criticisms via sleuthing is, problematically, a demonstration of subjective power and privilege. However, these critiques provide an important counternarrative to existing power structures that continue to use the binary between reason and relationship to justify institutionalized prejudice and oppression. 


\section{CHAPTER III: MOTIVATION \& MECHANISM: ADOLESCENT SLEUTHS IN RELATIONSHIP}

"The people in the Sleuths' lives bring a world of experience that the teens themselves may not have. The gang $[\ldots]$ can accomplish way more together than they can alone.”

- BubbleGumshoe (Boss, et al., 87)

"We are both free and bound in our circles and chains."

- Caring (Noddings 48)

In her analysis of Margaret Sutton's Judy Bolton mystery series, Mary Jeanette Moran examines how Judy negotiates an ethic of care in a patriarchal society that "encourages women to locate all their self-worth in nurturing others" (Moran 23). Judy's ability to find strength in relationality while challenging patriarchal expectations of female martyrdom, Moran suggests, is unique in that her "willingness to depend on others does not weaken her but rather presents a positive image of a different kind of strength, one that comes from interdependence rather than independence" (23).

As Moran's analysis outlines in detail, Judy's unique strength is foundational to her approach to sleuthing in the mystery series. In this chapter, I am interested in extending Moran's analysis of Judy Bolton's use of relationship in ethical reasoning to other adolescent sleuthing stories. First, I will once again visit Sammy Keyes and Alex Rider as single-agent sleuths, or sleuths who act as the primary sleuthing agent within the narrative. Then I will look at two examples of multi-agent sleuthing stories, in which multiple adolescent protagonists work 
collectively as sleuths toward a common goal: A.J. Butcher's Spy High series wherein Jake, Ben, Lori, Eddie, Cally, and Jennifer (collectively referred to as Bond Team) are students at a spy training facility masked as a high school; and the role-playing game BubbleGumshoe: A Teen Detective Story Game, created by Emily Care Boss, Kenneth Hite, and Lisa Steele, wherein players act as teen sleuths to solve a mystery.

In the previous chapters I have demonstrated how moral reasoning and subjective power are integral to the sleuthing process. In this chapter, I will focus on relationality, exploring how relationships impact, and are impacted by, adolescent sleuths as they engage in sleuthing. My analysis of Sammy Keyes and Alex Rider will demonstrate that, in their negotiations of the separation and attachment dilemma, single-agent adolescent sleuths often emphasize relationship as a motivation for sleuthing. This is an interesting contrast to multi-agent adolescent sleuthing stories, such as Spy High and BubbleGumshoe, in which relationships are emphasized as a critical mechanism or tool of sleuthing. While single-agent and multi-agent sleuthing each come with their own implications, they both frame relationships as a key component of (adolescent) sleuthing. However, the genre also suffers from the aetonormative assumption that adolescent sleuths are incapable of acting independently, as opposed to their adult counterparts.

\section{The Single-Agent Sleuth}

Separation as Caring

In the previous chapters, I have demonstrated how Sammy and Alex each negotiate the separation versus attachment dilemma in such a way that care often plays a pivotal role in motivating the adolescent protagonist to become a sleuth. In Caring: A Relational Approach to Ethics and Moral Education, Nel Noddings uses the term one-caring to describe a person who is 
enacting care in some way toward another and cared-for to describe the recipient of that care. Sammy and Alex both act as ones-caring, and sleuthing is the means through which they choose to perform that care: Sammy wants to help Gina without endangering Grams, and Alex wants to affirm his relationship with Ian without endangering Jack. Sammy and Alex see sleuthing as imperative to fulfilling their roles as ones-caring, so through these more intimate relationships friendship and familial love - Sammy and Alex, as ones-caring, are motivated to become sleuths. Sleuthing and caring are integrally related acts in these stories: sleuthing enables caring, and caring enables sleuthing.

Noddings calls these close relationships circles of caring and identifies different "circles" according to levels of closeness to the individual. The innermost circle is the most intimate and includes those that we love; next, moving outward, are "those for whom we have personal regard" but may not necessarily love. These "circles of proximate others" can be broken down further, but Noddings breaks them down generally into these two categories. Outside of an individual's circles of caring are people they have yet to meet but are prepared to meet through those circles of caring; Noddings gives the example of a future son-in-law whom she has yet to meet but anticipates meeting someday who will enter her life "with potential love." Noddings uses chains of caring to describe these anticipated relationships with people toward whom she is "prepared to care." Where a person is placed within our circles and chains defines how we view ourselves in relationship to the other person and can determine how we act as one-caring toward them. Within our circles, "we are guided in what we do by at least three considerations: how we feel, what the other expects of us, and what the situational relationship requires of us" (46). The more intimately we feel toward a person, the more resources we have to apply contextual reasoning toward that person. The more disconnected we feel toward a person - for example, a 
person who is a complete stranger to us, who does not exist within our circles or chains - the more we rely on social rules and our own moral principles. Noddings reflects that "[w]e are both free and bound within our circles and chains" - meaning that while our circles and chains can give us flexibility to engage with individual people in individual situations as such, they can also place pressures on us that are imposed by greater social structures and expectations (48). This metaphor harkens back to Carol Gilligan's theories about the attachment versus separation dilemma, as well as Sara Ruddick's claims about gendered delineations of principled/abstract and contextual/concrete reasoning: Noddings associates greater attachment with contextual/concrete reasoning and greater separation with principled/abstract reasoning.

While Sammy and Alex, as ones-caring, are compelled to become sleuths as an act of care toward their cared-fors, there is an irony in how the single-agent adolescent sleuth navigates the separation versus attachment dilemma as one-caring. Even with an emphasis on the singleagent sleuth as one-caring, as in the examples of Sammy and Alex, the one-caring must also embrace a certain degree of separation in order to enact that care. Sammy keeps her interaction with the hotel thief a secret from her grandmother out of concern for her emotional wellbeing, and even though she is seen to engage in many caring relationships throughout the text, which demonstrates that Sammy generally is not a loner, much of her sleuthing is enacted alone; this sleuthing strategy is framed as necessary in Sammy's responsibilities as one-caring. Similarly, Alex doesn't tell Jack about his growing suspicions regarding "the bank" that Ian worked for ("She had enough on her mind" - Horowitz 24) and investigates the circumstances of Ian's death by himself; in subsequent installments of the series, Alex continues to "work for" MI6 out of an imperative to protect Jack, even though he continually keeps the dangerous nature of his "work" from Jack and finds himself growing increasingly isolated from his peers at school. Neither of 
these characters relish separating themselves from their friends and loved ones, but they recognize the separation as necessary in order to protect their loved ones' mental, emotional, and occasionally physical well-being.

Importantly, these acts of caring separation, or separation as caring, often leave the caredfors ignorant of the precise extent to which the one-caring has endangered themselves in order to perform the caring act. If they are given any information at all, like Grams or Jack are, their knowledge of events is generally limited to whatever the sleuth feels strikes the best balance between what is necessary to share and what can afford to be spared out of concern for the caredfor's well-being. This raises a question of reciprocity in these caring relationships. Regarding reciprocity, Noddings explains:

[W] relate most closely to those that respond to us with seeming interest and affection. Such response is exactly what care ethics refers to as reciprocity. We are not talking about contractual reciprocity. We do not expect cared-fors, whether human or animal, to do for us what we do for them, nor do we expect payment of some sort. Instead, we look for signs that our caring has been received. What we do by way of caring satisfies a need in the cared-for, completes the caring relation, and enriches our lives as carers. (xviii, italics in original)

Using this conceptualization of reciprocity, anyone who benefits from Sammy's and Alex's sleuthing behaviors is reciprocating if they can be seen to have received the effects of the sleuthing - Grams remaining safely housed in the Senior Highrise, and Jack remaining in England without getting deported - even if they are not completely savvy as to all of the dangerous situations that their one-caring has performed for them in the name of protecting them. This dynamic is framed as necessary for the adolescent sleuth who believes that limiting 
information constitutes an act of care. This structure subverts the trope described by Chris McGee, in which an adult character withholds knowledge from a child detective, thus marking the child detective story with a power struggle centered around the withholding and obtaining of that knowledge. In the cases of Sammy and Alex, the focus is on the adolescent character choosing to withhold information from an adult character, and this choice is emphasized as an act of care. This dynamic may frame this form of caring separation as a valid and even noble choice, but it also feeds into a problematic narrative that conflates caring as self-sacrifice.

\section{Sleuthing as Self-Sacrifice}

As I have described previously, expectations of care and justice are problematically delineated to uphold systems of oppression. The roles that care and justice play in these systems continue to be used for the society, first, to assign the expectation, responsibility, and labor of care (love, relationship, attachment, connection) to the most marginalized individuals while assigning the expectation, responsibility, and labor of justice ("reason," "rationality," rules, principles, separation, individualism) to the least marginalized individuals; second, to value justice ethics as implicitly superior to care ethics; and third, to consider the resulting patterns of behavior not as a result of enculturation, but as a justification for keeping the systems of domination and oppression in place.

This paradigm has led to many problematic stereotypes that place the expectation of certain behaviors on certain individuals based on their subjective positionalities; for example, women, and especially women of color, are disproportionately expected to perform labors of care. Several scholars, such as Magnet, et al, Hill Collins, Noddings, and Moran, have written extensively about how, as women have been expected to take on the labor of care, they have also 
been expected to express that care through self-sacrificial behavior. This expectation ensures that women will provide the labor of care which on a very basic level is necessary for the survival of the human race, and that they will provide this labor without the expectation of compensation to which other forms of labor are entitled.

As I noted earlier, Moran examines how Judy Bolton negotiates an ethic of care in a patriarchal society that "encourages women to locate all their self-worth in nurturing others" (23). Judy's ability to find strength in relationality while challenging patriarchal expectations of female martyrdom, Moran suggests, is unique in that her "willingness to depend on others does not weaken her but rather presents a positive image of a different kind of strength, one that comes from interdependence rather than independence" (23). Moran notes that "[f]eminist ethicists have discussed at length this alternative model of strength, many suggesting that guidelines for behavior should be centered around the premise of relationality: People are not isolated entities, but members of interconnected communities that shape and influence them as individuals and to which they owe responsibility" (23). This analysis of Judy Bolton demonstrates that it is possible for the adolescent sleuth to find strength in relationship without falling into the problematic trap of martyrdom.

In the examples of Sammy Keyes and Alex Rider, both of these characters demonstrate the self-sacrificial behavior that has raised such concern among feminist ethicists. Sammy chooses to come forward with her testimony despite the risk in drawing the attention of the police toward herself and her grandmother; moreover, she puts herself in physical danger when she sets the final trap to catch the hotel thief. Alex puts himself in danger when he jumps from Crawley's office window to Ian's, both physically and at the risk of being caught; he also 
"consents" to finish the same mission that got Ian killed (so even though MI6 assures Alex that he will be perfectly safe, the situation is sure to be a dangerous one).

As I described in the previous chapter, the "girl sleuth" genre to which Sammy can be ascribed has a history of characters who are women and who provide their sleuthing skills as a means of contributing to their community: they are not financially compensated for their sleuthing labors, they just do it because it is their moral imperative (and subjective privilege) to do so. Consider this final passage in Hotel Thief:

I know Grams is going to keep me up all night. First she'll want to hear the whole story. From the top. Then she'll want to hear it again. Then [...] she'll blame everything on the binoculars and make me promise never to use them again.

A promise she knows I just can't keep. (163, italics in original)

This passage, particularly the final sentence, emphasizes sleuthing as a compulsion for Sammy; she sleuths because she wants to. Sammy is intrinsically motivated to sleuth, and this fact of her character serves as an explanation as to why she does not expect compensation for having done the work of catching the thief which was supposed to have been done by the police (who are, unlike Sammy, financially compensated for their labor).

Sammy's intrinsic love of sleuthing stands in stark contrast to Alex's feelings toward the matter. As I have described previously, his sleuthing behaviors aren't entirely obligatory everything he does to investigate the circumstances of Ian's death is entirely of his own volition - but he feels bitter about the whole ordeal. Once he has enough answers to satisfy his own curiosities and affirm his relationship with Ian, Alex wants nothing more to do with the matter. As Alex says to Blunt and Mrs. Jones: "I'll sign the Official Secrets Act or whatever it is you want me to do, but then I'd like to go home. This is all crazy, anyway. And I've had enough. I'm 
out of here" (36). And Alex's feelings toward sleuthing do not improve by the end of the novel. Walking away from MI6 after being debriefed on the completed mission, Alex reflects back on the events he has experienced:

He should have been feeling better. As he took the elevator down to the ground floor, he reflected that he'd saved thousands of schoolchildren, he'd beaten Herod Sayle, and he hadn't been killed or even badly hurt. So what was there to be unhappy about? The answer was simple. Blunt had forced him into this $[\ldots .].[\mathrm{H}] \mathrm{e}$ 'd never been given a choice. Nowadays, spies weren't employed. They were used. (186-87)

In the case of this particular boy sleuth, while sleuthing is presented as a moral imperative, the ways in which Alex is being exploited by MI6 are highlighted throughout the narrative. The novel explicitly problematizes the fact that Alex is not positively compensated for his labor and is instead manipulated into performing this labor out of fear of Blunt's threats to deport Jack and send Alex to boarding school. These stories fit into a problematic pattern of women being expected to provide labor out of a moral compulsion, to consider the labor itself to be intrinsically rewarding, while men are expected to be extrinsically compensated for their labor and are shown to be reasonably frustrated when this expectation is not met.

Both Sammy and Alex engage with sleuthing as a moral action in their imperatives as ones-caring, they both put themselves at risk in order to fulfill this imperative, and neither of them are compensated for their labor. The difference between the two is that Sammy feels satisfied with these circumstances, while Alex feels exploited. For the girl sleuth, sleuthing as self-sacrifice is a pleasure and a privilege; for the boy sleuth, sleuthing as self-sacrifice is an obligation, a chore. This self-sacrifice is typical for female protagonists, but not for males; what makes Alex different from his salaried colleagues in MI6 is that he is young and therefore able to 
be exploited. The adolescent sleuth is expected to provide the labor of sleuthing uncompensated, and while the sleuth's gender determines how and to what degree this dynamic is questioned within the narrative, the sleuth's young age creates an expectation of self-sacrifice that supersedes gendered privileges.

\section{Multi-Agent Sleuthing}

The format of the single-agent sleuthing story allows for the narrative to focus on the sleuth as one-caring. However, the structure of the single-sleuth story is still hyper-focused on the individual and lends itself to the ironic trope of separation as caring. As I will demonstrate in this section, the multi-agent sleuthing story provides an opportunity to de-emphasize the individual and focus on relationships. While for the single-agent sleuth relationships are emphasized as a motivation for sleuthing, multi-agent sleuthing stories emphasize relationships as critical tools for sleuthing. This shifts the narrative purpose of these relationships from the reason for sleuthing to the mechanism through which sleuthing happens. Additionally, when relationships are emphasized as a mechanism or tool for effective sleuthing, these narratives tend to emphasize relationships as things which must be maintained, a task that requires labor from all parties; this stands in contrast to the self-sacrificial relationships that are centered in single-agent sleuthing stories, which focus more on the labor being done by the one-caring.

\section{Relationship as Mechanism}

In Spy High: Mission One, Deveraux Academy (colloquially referred to as Spy High) is a government-operated facility for training adolescents to become spies. A key component of this institution is that it places students in teams in order to emphasize the importance of teamwork 
and collaboration in being an effective spy. Jake, Ben, Lori, Eddie, Cally, and Jennifer are assigned to work together as a team, collectively referred to as Bond Team. However, Bond Team struggles to gel until Spy High forces them into a life-threatening situation without their consent and leaves Bond Team without help. In doubting the credibility and trustworthiness of Deveraux Academy, Bond Team is finally able to work together as a team. In critiquing this governmental institutional authority, the members of Bond Team also fulfill the role of that same authority and defeat the villain, Dr. Averill. Spy High: Mission One thus meets the conventions of the adolescent sleuthing story as I have described them. Bond Team differs from Sammy and Alex, however, in that they are not acting alone as single-agent sleuths; they are a multi-agent team of sleuths. Whereas Sammy and Alex become sleuths in order to fulfill their responsibilities as ones-caring for other people, the members of Bond Team ultimately join together because their individual survival depends on the survival of the group.

At the book's opening, Bond Team is struggling more than any other team at Spy High to work together. Every team is expected to pass the Stromfeld Test, a virtual reality program designed to mimic a real mission. Bond Team is the only team unable to pass the test. The narrative emphasizes two members of the team as being particularly responsible for this dynamic:

Jake, brooding, intense, uncompromising, crackling with energy even in two dimensions. Ben, arrogant, aloof, aristocratic, certain of himself and his place in the world. Jake's unruly black hair to Ben's regimented blond. Opposites. Opposites intended to work together. The perfect balance - that had been Grant's plan. Only the plan didn't seem to be working. So far between Jake and Ben it was all conflict and no cooperation. Maybe he'd been too optimistic. Maybe the two of them would never gel. 
Maybe Ben would never gel with anyone. (31)

The conflict between Jake and Ben infects the rest of the group. As Jake and Ben quarrel over who will be named team leader (a high honor at Spy High), the rest of the group becomes fissured as well. As the conflict continues, each member of the group becomes increasingly concerned with his/her individual needs/success and less concerned with that of the group. For example, when Senior Tutor Grant tells Bond Team that they are being sent on a "camping trip" in order to bond as a team, Jennifer asks to be exempted from the trip: “[T]his isn't what I signed up for. I can't just run off into the woods - it's a waste of my time." Grant responds, "This is not an option, Jennifer. It's an order. And your outburst - placing your own agenda ahead of the interests of the team - is exactly why you have yet to pass the Stromfeld program" (110). With the understanding that no members of Bond Team will be allowed to graduate from Spy High if they do not learn how to cooperate, they agree to participate in the "camping trip." What Bond Team does not know is that they are being sent to The Wildscape, a location in which there have been several disappearances, including one of Spy High's own graduates.

When Bond Team realizes that Grant has sent Bond Team into known danger without telling them, they recognize the deception as a signal that "we can't rely on Spy High for help" (163). In this moment, Bond Team realizes that if any of them wishes to survive this dangerous scenario, each of them will have to start relying on each other rather than on the governmental institutional authority of Deveraux Academy. The survival of the group and the survival of the individual has become inseparable. This means that each member of Bond Team needs not just to view their teammates as assets to individual success, but also to view each of themselves as an asset to their teammates. As the situation escalates, the members of Bond Team become increasingly appreciative and protective of each other. For example, when Lori, Jennifer, and 
Ben are imprisoned by the evil Dr. Averill, Ben reflects that "They all were [unharmed], and while that was the case, they had a chance" (141). Reflections and statements to this effect appear with increasing frequency as the danger mounts. As each member of Bond Team learns to set aside their ego and trust in each other, they are rewarded with survival. Each member of Bond Team plays a critical role in their survival, which demonstrates the necessity of relationships as a mechanism of multi-agent sleuthing.

After they defeat Dr. Averill - Ben calls the whole incident "Bond Team's baptism of fire" (178) - and return safely to Spy High, the first installment of the series comes to a close with Bond Team finally beating the Stromfeld program with flying colors (188). This final reward further underscores the narrative's continued emphasis on teamwork as an essential skill for the professional spy. Unlike the single-agent sleuth, whose motive for sleuthing is rooted in their relationship as one-caring, multi-agent sleuths rely on their relationships as a key mechanism without which their sleuthing would not be successful. This also contrasts with the tendency of self-sacrificial behaviors exhibited in single-agent sleuthing stories; whereas Sammy and Alex endanger themselves in the pursuit of protecting their loved ones, every member of Bond Team must survive in order for any them to survive. In the case of Bond Team, selfsacrificial behavior is just as harmful to the group as it is to the individual.

\section{Relationship as Compensation}

While emphasizing relationships as a critical mechanism of sleuthing positions the multiagent sleuthing story against the problematic trope of self-sacrifice evident in single-agent sleuthing stories, the multi-agent sleuthing story also risks suggesting that adolescent sleuths, as opposed to their adult counterparts, don't just benefit from group support but need it in order to 
compensate for individual deficits that are rooted in adolescence. This aetonormative paradigm is overt in BubbleGumshoe: A Teen Detective Story Game. As in single-agent sleuthing stories, this role-playing game identifies relationships as a key motivation for sleuthing: "When [family and friends] get threatened, it's time for the Sleuths to go into action and see what they can do to help the ones they care about" (86). Additionally, as in Spy High, in BubbleGumshoe relationships are seen as key mechanisms within sleuthing, and worth carefully maintaining: "These Relationships also provide boosts to the Sleuths' ongoing investigations. But push them too far, and you'll need to work on getting back in their good graces. Push the investigation too far, and it may put the people you love most in danger!" (86).

Relationships must be navigated appropriately throughout the game, as they are key to accessing various resources. If Sleuths are not careful with their Relationships this may sabotage the Sleuths' ability to solve the mystery and win the game (24-32). For example, a Sleuth may have a friend who has a key to an important room. If the Sleuth lies to their friend and the friend becomes angry with them as a response, the Sleuth will likely lose access to the key and be unable to access that room, potentially jeopardizing their ability to solve the mystery and win the game. While each player is required to have an individual motivation to invest themselves in the mystery at hand, a motivation that explicitly positions the Sleuth as one-caring, they cannot successfully navigate the game as single-agent sleuths serving solely their own interests; they must work together with the other players and with non-player characters and achieve a balance between individual and collective interests. As in Spy High, everyone's interests in BubbleGumshoe must be catered to, or nobody's will be.

As a tabletop roleplaying game, the rhetorical situation of a game of BubbleGumshoe is typically a group of real-life friends who wish to enjoy a group activity together. However, in 
order for the game to function smoothly, it is necessary to construct an in-game justification for why these particular characters have come together. Players will typically construct their characters to balance out the party, giving individual characters their own skills and relational networks while ensuring that the party has enough collective resources to work toward the common goal of solving the mystery at hand. This ensures that the game functions internally while achieving the external goal of participating in a group activity. Yet the BubbleGumshoe manual provides an additional explanation for the game's emphasis on relationships that is based not on an out-of-game necessity that can be applied to most RPGs, but on an aetonormative assessment of adolescents as being deficient compared to their adult counterparts:

The teen investigators in this game are talented, smart, thoughtful people. They have many skills that will help them take action to help others and get themselves out of trouble. However, they are still teenagers. Their experience of the world is limited to what they've learned from going to high school and surfing the web. They may have a lot of opinions but not as much experience as they think they do. This is where Relationships come in handy [.... The people in the Sleuths' lives bring a world of experience that the teens themselves may not have. The gang gets together for the same reason - they can accomplish way more together than they can alone. (87; italics added)

This excerpt explains that relationships are necessary for the adolescent sleuth (and implies that this is not true for the adult sleuth) because teenagers are "limited" in their own knowledge and skills to "what they've learned from going to high school and surfing the web." Relationships, for the adolescent sleuth, serve as compensation for the aetonormative assumption that all teenagers are, by nature, incapable of single-agent sleuthing due to an inherent lack of experience. 
This assertion suggests that adult sleuths do not rely on relational networks. However, several of the scholars I have cited thus far have emphasized that we are always acting and existing in relationship, regardless of age. Marilyn French's explanation of this reality, from Beyond Power: Men, Women, and Morals, is particularly useful here:

At every level self is part of group, group is part of self. Alasdair MacIntyre points to the absurdity of the modern notion that extrication from group - family, tribe, village, community, society - means freedom, when in fact one's group identity is intrinsic to one's personal identity, whether we like that or not, whether we admit it or not. Our insistence on individuality, independence, freedom defined as freedom from bonds to others, has fostered competitiveness and rivalry; together, these values have made modern life a battle-ground, a noisy, dangerous, filthy, urban nightmare, from which the only relief is isolation and retreat. (504)

This connects clearly to the previous claims I have presented by care ethics scholars regarding the separation versus attachment dilemma, care versus justice ethics, reason versus relationship, and the gendered (among other things) implications thereof. Here French points out that true independence, complete separation from others, is a myth - the myth that props up the patriarchy, capitalism, and other forms of oppression. Those with the most power in our society tend to identify that power in their sense of "freedom from bonds to others." Yet power can only be granted through others, and without those others, the power would not exist:

Power is a process, a dynamic interaction. To have power really means to have entry to a network of relationships in which one can influence, persuade, threaten, or cajole others to do what one wants or needs them to do. Although no other syntax is available to us, it is in fact false to speak of "having power." One does not possess power: it is granted to 
the dominator by hosts of other people, and that grant is not unretractable[.] (509, italics in original)

This conceptualization of power emphasizes the relational nature of power, and challenges the idea that power is obtained through separation. Thus, the assertions that adolescent sleuths are unique in their reliance on others, as opposed to their adult counterparts, and that this reliance is evidence of some kind of deficit within the adolescent sleuth, are problematically aetonormative. Additionally, these claims contribute to the narrative that values the masculinized ideals of separation, justice, and reason as superior and only belonging to the elite classes (in this case, adult sleuths) while relegating the feminized ideals of attachment, care, and relationship to the oppressed, and using these dynamics to justify and perpetuate these systems of oppression.

\section{Conclusion}

Single-agent sleuthing stories, such as those of Sammy Keyes and Alex Rider, emphasize relationship as a motivation for sleuthing. As Sammy and Alex see that adult law enforcement officials are not fulfilling their designated roles, leaving these sleuths' loved ones unprotected, Sammy and Alex are motivated to step into those roles as an act of care. While Officer Borsch and MI6 agents have consented to the labor of law enforcement within the structures of employment contracts, Sammy and Alex must perform the same labor without compensation. Sammy and Alex are motivated out of care, not out of external compensation. Because they are young, these single-agent sleuths are expected to martyr themselves as an act of care. Thus, the single-agent sleuthing story problematically conflates self-sacrifice as caring.

Conversely, multi-agent sleuthing stories emphasize relationship as a critical mechanism for sleuthing. When multiple sleuths work together, such as in Spy High and BubbleGumshoe, 
self-sacrifice is as dangerous for the group as it is for the individual. Self-sacrifice does not constitute an act of care in these cases; rather, in viewing all members of the group, including themselves, as integral to the sleuthing process, sleuths must care for themselves if they wish to care for other people (and vice versa). This challenges the notion set by single-agent sleuthing stories that young people are required to engage in self-sacrificial behavior in order to fulfill their imperative as one-caring. However, the multi-agent sleuthing story is implicated by the aetonormative assumption that adolescents must work in groups because, as adolescents, they are not yet capable of acting "independently" as their adult counterparts supposedly do.

\section{Coda: A Final Statement}

In the first chapter of this thesis, I demonstrated that adolescent sleuthing stories highlight gaps in governmental institutional authority which force the adolescent protagonist into a moral dilemma of separation versus attachment. Sammy Keyes and Alex Rider are examples of sleuths who respond to this dilemma through the contextual reasoning and relational motivation associated with an ethic of care, which stands in contrast to the principled ethic of justice consistently associated with the legal authorities in these narratives. Sammy and Alex implement an ethic of care in order to challenge these institutions and question their over-reliance on an ethic of justice. This anti-establishmentarian theme presents a unique potential for sleuthing stories to challenge a system that manipulates reason and relationship to sustain oppressive power.

However, as I established in the second chapter, the progressive powers of this genre have been limited in their application. This is particularly evident in the genre's tendency to empower white protagonists at the expense or erasure of marginalized groups. The rise of the 
"girl sleuth" is a key example of how white women have been able to leverage their whiteness in order to gain access to a traditionally masculine genre. The "girl sleuth" has historically earned her way into the sphere of detective fiction by demonstrating that her gender will not prevent her from enforcing and benefitting from white supremacy and other forms of systemic oppression. Similarly, Sammy and Alex, as adolescent sleuths, also leverage their subjective powers and privileges in order to overcome their age-dependent oppression. While adolescent sleuths are critical of oppressive systems to a point, they are only enabled to enact those criticisms because of their own privileges and complicity in a system that grants them those privileges while denying them to others. While chapter one shows how adolescent sleuths are often motivated to sleuth through an ethic of care, chapter two shows that this valuing of attachment is limited to the sleuth's closest circles of caring. When a sleuth relies on institutional power to act as one-caring, this demonstrates a symbolic detachment from those whose institutional oppression is the cost of that power.

Sammy and Alex are the protagonists of single-agent sleuthing stories, which emphasize individuality and independence. These mythical concepts are necessary in order to justify separation between groups of people based on their positioning within the symbolic order of oppression. Multi-agent sleuthing stories such as Spy High and BubbleGumshoe question these ideas, emphasizing relationality and connection to others as a key component of successful sleuthing. This is important because it underscores the notion that "independence" is a projection of privilege. However, BubbleGumshoe makes the problematic assertion that this emphasis on relationality is unique to adolescent sleuthing stories and relies on the aetonormative assumption that adolescence is marked by an inability to act independently. This relegates an ethic of care, relationship, and attachment to the sphere of adolescence and childhood (a subjugated position) 
while relegating an ethic of justice, detachment, and separation to the sphere of adulthood (a position of power). Associating youth with an ethic of care while associating adulthood with an ethic of justice serves to infantilize care ethics while valorizing justice ethics as a mark of maturity. This aetonormative affiliation between maturity and morality also serves to perpetuate the problematic history of using care and justice ethics to assert that oppressors have earned their power through an inherent moral superiority over the oppressed.

Viewing adolescent sleuthing as a moral response to oppression highlights the sleuthing story's unique ability to challenge the problematic binary between reason and relationship that is used to justify and enable institutional oppression. However, this potential is limited when sleuthing is portrayed as the mechanism through which the individual is enabled to rise from oppression by becoming the oppressor. If this problematic trope can be dismantled, it is my contention that the single-agent sleuthing story's emphasis on care ethics and the multi-agent sleuthing story's emphasis on relationality can be capitalized on to continue and expand the sleuthing story's long history as a counternarrative to oppressive systems. 


\section{WORKS CITED}

Boss, Emily, Kenneth Hite, and Lisa Steele. BubbleGumshoe: A Teen Detective Story Game. Evil Hat Productions, LLC, 2016.

Breu, Christopher. Hard-Boiled Masculinities. Regents of the University of Minnesota, 2005

Butcher, A.J. Spy High: Mission One. First U.S. Edition. Atom Books, 2003.

Collins, Patricia Hill. Black Feminist Thought: Knowledge, Consciousness, and the Politics of Empowerment. 1990. Routledge, 1991.

Dyer, Carolyn Stewart and Nancy Tillman Romalov, editors. Rediscovering Nancy Drew. University of Iowa Press, 1995.

French, Marilyn. Beyond Power: On Women, Men, and Morals. Belles-Lettres, Inc., 1985.

Friere, Paolo. Pedagogy of the Oppressed. 1970. Translated by Myra Bergman Ramos, The Continuum International Publishing Group Inc., 2005.

Gilligan, Carol. In a Different Voice: Psychological Theory and Women's Development. 1982. Harvard University Press, 1993.

Held, Virginia. The Ethics of Care: Personal, Political, and Global. Oxford University Press, 2006.

Hintz, Carrie and Eric L. Tribunella. Reading Children's Literature: A Critical Introduction. Bedford/St. Martin’s, 2013, pp. 13-29.

Horowitz, Anthony. Stormbreaker. Scholastic Inc., 2000.

Kohlberg, Lawrence, and Richard H. Hersh. "Moral Development: A Review of the Theory." Theory into Practice, vol. 16, no. 2, Apr. 1977, pp. 53-59.

Magnet, et al. "Feminism, Pedagogy, and the Politics of Kindness.” Feminist Teacher, vol. 25, no. 1, 2016, pp. 1-22. 
Mason, Bobbie Ann. The Girl Sleuth: A Feminist Guide. The Feminist Press, 1975.

McGee, Chris. "The Mysterious Childhood: The Child Detective from the Hardy Boys to Harry Potter.” Illinois State University, PhD Dissertation, 2004.

Moran, Mary Jeanette. "“Use Your Head, Judy Girl': Relationships, Writing, and an Ethic of Care in the Judy Bolton Mysteries." Clues: A Journal of Detection, vol. 27, no. 1, Spring 2009, pp. 22-32.

Nikolajeva, Maria. Power, Voice and Subjectivity in Literature for Young Readers. Routledge, 2010.

Noddings, Nel. Caring: A Relational Approach to Ethics and Moral Education. 1984. Second Edition, Updated, University of California Press, 2013.

Penzler, Otto, editor. Black Noir: Mystery, Crime, and Suspense Fiction by African-American Writers. Pegasus Books LLC, 2009.

Ruddick, Sara. Maternal Thinking: Toward a Politics of Peace. Beacon Press, 1989.

Trites, Roberta Seelinger. Disturbing the Universe: Power and Repression in Adolescent Literature. University of Iowa Press, 2000.

Van Draanen, Wendelin. Sammy Keyes and the Hotel Thief. Scholastic Inc., 1998.

Weinman, Sarah. "The Case of the Disappearing Black Detective Novel." The New Republic, 8 Dec. 2015, https://newrepublic.com/article/124468/case-disappearing-black-detectivenovel. 